\title{
Climate change impacts on net primary production (NPP) and export production (EP) regulated by increasing stratification and phytoplankton community structure in the CMIP5 models
}

\author{
Weiwei Fu, James T. Randerson, and J. Keith Moore \\ Department of Earth System Science, University of California, Irvine, California, 92697, USA \\ Correspondence to: Weiwei Fu (weiweif@uci.edu) \\ Received: 16 June 2015 - Published in Biogeosciences Discuss.: 12 August 2015 \\ Revised: 10 July 2016 - Accepted: 3 August 2016 - Published: 16 September 2016
}

\begin{abstract}
We examine climate change impacts on net primary production (NPP) and export production (sinking particulate flux; EP) with simulations from nine Earth system models (ESMs) performed in the framework of the fifth phase of the Coupled Model Intercomparison Project (CMIP5). Global NPP and EP are reduced by the end of the century for the intense warming scenario of Representative Concentration Pathway (RCP) 8.5. Relative to the 1990s, NPP in the 2090 s is reduced by $2-16 \%$ and EP by $7-18 \%$. The models with the largest increases in stratification (and largest relative declines in NPP and EP) also show the largest positive biases in stratification for the contemporary period, suggesting overestimation of climate change impacts on NPP and EP. All of the CMIP5 models show an increase in stratification in response to surface-ocean warming and freshening, which is accompanied by decreases in surface nutrients, NPP and EP.

There is considerable variability across the models in the magnitudes of NPP, EP, surface nutrient concentrations and their perturbations by climate change. The negative response of NPP and EP to increasing stratification reflects primarily a bottom-up control, as upward nutrient flux declines at the global scale. Models with dynamic phytoplankton community structure show larger declines in EP than in NPP. This pattern is driven by phytoplankton community composition shifts, with reductions in productivity by large phytoplankton as smaller phytoplankton (which export less efficiently) are favored under the increasing nutrient stress. Thus, the projections of the NPP response to climate change are critically dependent on the simulated phytoplankton community structure, the efficiency of the biological pump and the resulting levels of regenerated production, which vary widely across
\end{abstract}

the models. Community structure is represented simply in the CMIP5 models, and should be expanded to better capture the spatial patterns and climate-driven changes in export efficiency.

\section{Introduction}

Ocean net primary production (NPP) and particulate organic carbon export (EP) are key elements of marine biogeochemistry that are vulnerable to ongoing climate change from rising concentrations of atmospheric $\mathrm{CO}_{2}$ and other greenhouse gases. Ocean warming has increasing impacts on ocean ecosystems by modifying the ecophysiology and distribution of marine organisms, and by altering ocean circulation and stratification. Ocean ecosystems also are important components of the climate system, influencing the atmospheric abundance of radiative agents such as $\mathrm{CO}_{2}, \mathrm{~N}_{2} \mathrm{O}$, aerosols and the bio-optical properties of seawater (Siegenthaler and Wenk, 1984; Goldstein et al., 2003; Manizza et al., 2008; Schmittner et al., 2008; Bopp et al., 2013). Therefore, understanding the mechanisms controlling NPP and EP is essential for understanding the global cycles of carbon and other bioactive elements, and their links to climate (Passow and Carlson, 2012).

Upper ocean stratification plays a key role in ocean biogeochemical processes. In particular, mixed layer depth (MLD) regulates the interplay between light availability for photosynthesis (Hannon et al., 2001) and nutrient supply to the upper ocean (Pollard et al., 2009). Upper ocean stratification is defined here as the density difference between the 
surface and $200 \mathrm{~m}$ depth (Capotondi et al., 2012), which is indicative of the degree of coupling and nutrient fluxes between the euphotic zone and the ocean interior. The density gradient at the base of the mixed layer affects entrainment processes, which play a crucial role in mixed layer deepening and in particle sinking/export from the euphotic zone. Stratification can also influence ocean ventilation (Luo et al., 2009), which has important consequences for oceanic uptake of carbon and oxygen. Thus, changes in stratification over the remainder of the 21 st century have the potential to influence NPP and EP across marine ecosystems.

Stratification tends to increase in response to ocean surface warming and freshening in 21 st century climate change simulations. Increased stratification reduces the input of subsurface nutrients to the euphotic zone and can lead to decreasing NPP and EP through increasing nutrient limitation. Many studies have suggested decreases in global NPP and EP over the 21st century using models with varying degrees of complexity (Bopp et al., 2001; Plattner et al., 2001; Fung et al., 2005; Schmittner et al., 2008; Steinacher et al., 2009; Dutkiewicz et al., 2013; Cabré et al., 2015). For the RCP8.5 scenario, CMIP5 ESM estimates of changes in export production range from -7 to $-18 \%$ relative to the $1990 \mathrm{~s}$, and for NPP these changes range from -2 to $-16 \%$ (Bopp et al., 2013).

The relative importance of different ecological controls on NPP and EP depends, in part, on an individual model's capacity to represent plankton functional types (PFTs) (Le Quéré et al., 2005; Jin et al., 2006) and their unique physiological and ecological characteristics, which determine how efficiently they are exported from surface waters. Increasing nutrient stress can shift phytoplankton community composition, favoring smaller phytoplankton, which are more efficient at nutrient uptake, over larger phytoplankton (Bopp et al., 2001; Steinacher et al., 2010; Vichi et al., 2011; Moore et al., 2013). These community shifts can modify the efficiency of carbon export. However, treatment of plankton communities is relatively simple in the CMIP5 models, with 1-3 phytoplankton functional types and typically one zooplankton group (Bopp et al., 2013).

Several previous studies examined the biogeochemical response to climate change in the CMIP5 models. Bopp et al. (2013) examined output from 10 CMIP5 models emphasizing model mean biogeochemical responses to multiple stressors and trends over the 21st century relative to 1990s means for each model. Cabré et al. (2015) analyzed the CMIP5 models examining changes between model output averaged over the period 1980-1999 with years 20802099. This study broke down the global output into different ocean biomes for analysis. Laufkötter et al. (2015) also analyzed output from nine coupled climate-carbon ESMs, including many of the CMIP5 models to study how climate change processes impact NPP, comparing two 20-year periods (2012-2031 and 2081-2100). They suggested strong roles for temperature and top-down grazing control in driv- ing the NPP response, particularly at lower latitudes. Both Cabré et al. (2015) and Laufkötter et al. (2015) conclude that changing light levels were not a primary driver of changes in NPP except at the highest latitudes where there were large decreases in sea ice cover. Thus, we do not consider light effects in this work, where our focus is on global-scale trends. More detailed regional studies of the CMIP5 model output have been carried out for the Arctic Ocean (Vancoppenolle et al., 2013) and the Southern Ocean (Hauck and Volker, 2015; Ito et al., 2015; Leung et al., 2015).

We analyzed centennial-scale changes in NPP and EP in response to increasing surface stratification and other physical factors. We use historical (1850-2005) and Representative Concentration Pathway (RCP) 8.5 (2006-2100) ESM simulations from the fifth phase of the Coupled Model Intercomparison Project (CMIP5) to study long-term trends in NPP and EP and to identify the mechanisms behind these changes, including the physical factors that regulate nutrient availability. We also examined variability in NPP, EP and surface nutrient concentrations across the models, to highlight some of the large differences and uncertainties in projections of climate change impacts on marine biogeochemistry in current-generation ESMs.

\section{Methods}

We analyzed simulations from a set of nine ESMs that contributed output to the Earth System Grid Federation as a part of CMIP5 (Taylor et al., 2012). Required physical ocean variables were temperature, salinity and potential density; required biogeochemistry variables were macronutrients (nitrate, phosphate and silicic acid), iron, chlorophyll, NPP and EP. The selection of the nine models investigated here (Table 1) was based on the availability of these variables.

The historical and RCP8.5 simulations we analyzed had prescribed atmospheric $\mathrm{CO}_{2}$ mole fractions and forcing from other greenhouse gases and aerosols, anthropogenic land use and solar variability. Volcanic forcing also was included during the historical period. The RCP8.5 is a strong warming scenario with an increase in radiative forcing of $8.5 \mathrm{~W} \mathrm{~m}^{-2}$ by 2100 as atmospheric $\mathrm{CO}_{2}$ mole fractions reach $936 \mathrm{ppm}$ (Moss et al., 2010; van Vuuren et al., 2011). In the case where several ensemble members were available from an individual ESM, we analyzed only the first member.

A simple description of the nine ESMs is presented in Tables 1 and 2. Atmospheric and ocean resolutions vary across the models (Table 1). Typical atmospheric horizontal grid resolution is $\sim 2^{\circ}$, but it ranges from 0.94 to $3.8^{\circ}$. Typical ocean horizontal resolution is $\sim 1^{\circ}$, ranging from 0.3 to $2^{\circ}$. In the vertical, there are $24-95$ levels in the atmosphere and 31-63 levels in the ocean. All marine biogeochemical components are nutrient-phytoplankton-zooplanktondetritus (NPZD) models, but with varying degrees of complexity illustrated, for instance, by the number of phytoplank- 
Table 1. A brief description of components of the ESMs used in this study. For atmosphere and ocean components, the number of levels in the vertical is indicated by "lev" and the horizontal resolution is indicated in degrees; vertical coordinates of the ocean and biogeochemical components are indicated by $Z$ (geopotential) or $I$ (isopycnal).

\begin{tabular}{|c|c|c|c|c|c|c|}
\hline \multirow[t]{2}{*}{ Model } & \multicolumn{2}{|c|}{ Resolution } & \multirow{2}{*}{$\begin{array}{l}\text { Vertical } \\
\text { coordinate }\end{array}$} & \multirow[t]{2}{*}{ Reference } & \multirow{2}{*}{$\begin{array}{l}\text { Biogeochemical } \\
\text { component }\end{array}$} & \multirow[t]{2}{*}{ References } \\
\hline & Atmosphere & Ocean & & & & \\
\hline GFDL-ES2M & 24 lev, $2.5 / 2.0^{\circ}$ & $50 \mathrm{lev}, 0,3-1^{\circ}$ & $Z$ & Dunne et al. (2013a) & TOPAZ2 & Dunne et al. (2013b) \\
\hline GFDL-ES2G & $24 \mathrm{lev}, 2.5 / 2.0^{\circ}$ & $50 \mathrm{lev}, 0,3-1^{\circ}$ & $Z+I$ & Dunne et al. (2013a) & TOPAZ2 & Dunne et al. (2013b) \\
\hline MPI-ESM-LR & $47 \mathrm{lev}, 1.9^{\circ}$ & $40 \mathrm{lev}, 1.5^{\circ}$ & $Z$ & Giorgetta et al. (2013) & HAMOCC5.2 & Ilyina et al. (2013) \\
\hline MPI-ESM-MR & $47 \mathrm{lev}, 1.9^{\circ}$ & $40 \mathrm{lev}, 0.4^{\circ}$ & $Z$ & Giorgetta et al. (2013) & HAMOCC5.2 & Ilyina et al. (2013) \\
\hline IPSL-CM5A-LR & $39 \mathrm{lev}, 1.9 / 3.8^{\circ}$ & $31 \mathrm{lev}, 0.5-2^{\circ}$ & $Z$ & Dufresne et al. (2013) & PISCES & Aumont and Bopp (2006) \\
\hline IPSL-CM5A-MR & $39 \mathrm{lev}, 1.2 / 1.9^{\circ}$ & 31 lev, $0.5-2^{\circ}$ & $Z$ & Dufresne et al. (2013) & PISCES & $\begin{array}{l}\text { Aumont and Bopp (2006) } \\
\text { Seferian et al. (2013) }\end{array}$ \\
\hline HadGEM2-ES & $38 \mathrm{lev}, 1.2 / 1.9^{\circ}$ & 40 lev, $0.3-1^{\circ}$ & $Z$ & $\begin{array}{l}\text { Jones et al. (2011) } \\
\text { Collins et al. (2011) }\end{array}$ & Diat-HadOCC & Palmer and Totterdell (2000) \\
\hline CESM1(BGC) & $26 \mathrm{lev}, 1.25 / 0.94^{\circ}$ & $\begin{array}{l}60 \text { lev, } 1.125^{\circ} \\
/ 0.27-0.53^{\circ}\end{array}$ & $Z$ & $\begin{array}{l}\text { Gent et al. (2011) } \\
\text { Lindsay et al. (2014) }\end{array}$ & BEC & $\begin{array}{l}\text { Moore et al. (2004) } \\
\text { Doney et al. (2009) }\end{array}$ \\
\hline NorESM1-ME & $26 \mathrm{lev}, 1.9^{\circ}$ & $70 \mathrm{lev}, 1.5^{\circ}$ & $I$ & Bentsen et al. (2013) & HAMOCC5.1 & Tjiputra et al. (2013) \\
\hline
\end{tabular}

ton functional groups (from 1 to 3 ) or limiting nutrients (from 3 to 5 ) that are explicitly represented (Table 2 ).

In our analysis, we used the CMIP5 variable denoting the vertical integration of NPP (intpp) and sinking export of organic particles at $100 \mathrm{~m}$ (EP; epc100). We present global mean estimates as the area-weighted or volume-weighted mean by the grid-cell area/volume from an individual model. Monthly mean data are averaged to obtain annual means and the annual mean data are interpolated onto a common $1^{\circ} \times 1^{\circ}$ regular grid for the comparison of the 2-D fields.

\section{Results}

\subsection{Stratification changes}

Stratification, defined here as the density difference between the depth of $200 \mathrm{~m}$ and the surface, is a useful indicator of change in the upper ocean, as it integrates changes in both temperature and salinity. In Fig. 1a, we present the time series of global mean stratification changes for the historical period and the RCP8.5 projection. All the models project an increase in stratification (ranging from 6 to $30 \%$ by the 2090s). However, the amplitude of stratification differs considerably across the models. The GFDL-ESM2M and MPI models are relatively close to the observed mean stratification in the WOA09 data set (red square, $1.81 \mathrm{~kg} \mathrm{~m}^{-3}$ ) for the present era. NorESM1-ME shows the weakest stratification $\left(1.74 \mathrm{~kg} \mathrm{~m}^{-3}\right)$ while the stratification in HadGEM2ES is strongest $\left(2.45 \mathrm{~kg} \mathrm{~m}^{-3}\right)$. Long-term trends are in general agreement across models, but the rate of stratification increase varies, with IPSL-CM5A-MR showing the most rapid increase and NorESM1-ME the slowest increase.

Surface processes that decrease density can largely explain the stratification increase in the RCP8.5 projections. Global mean sea surface temperature (SST) warms by 2.6$3.5^{\circ} \mathrm{C}$, accompanied by sea surface salinity (SSS) decreases

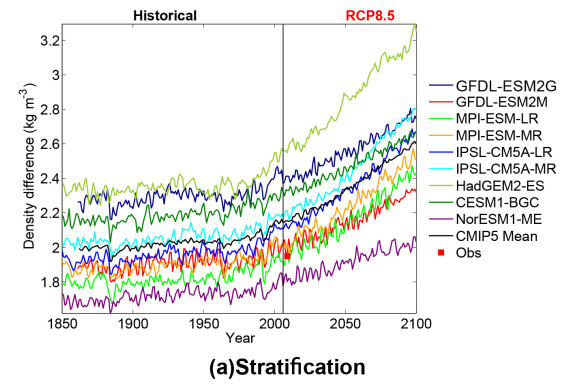

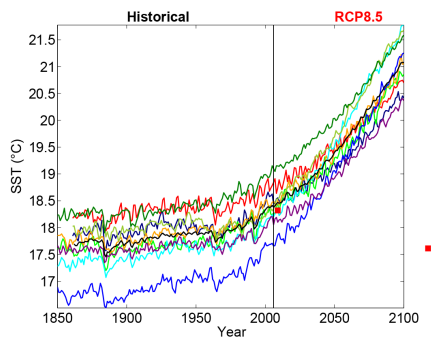

(b) SST

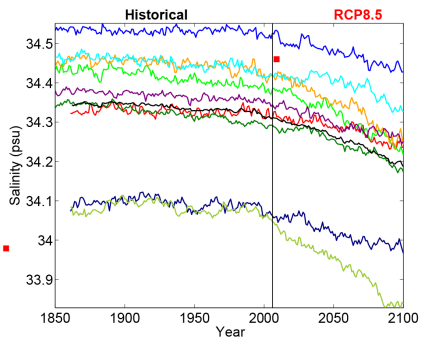

(c) SSS
Figure 1. Time series of global mean surface stratification, SST and SSS for historical run and RCP8.5 over 1850-2100. Surface stratification is defined as the density difference between $200 \mathrm{~m}$ and the surface. Red square indicates observations from the WOA2009 data.

of $0.05-0.25$ psu over the 21 st century (Fig. 1). By 2100, the global mean SST ranges from $20.4^{\circ} \mathrm{C}$ (HadGEM2-ES) to $21.8^{\circ} \mathrm{C}$ (NorESM1-ME). Model spread decreases in the $\mathrm{RCP} 8.5$ projections in response to strong anthropogenic forcing (Fig. 1b). SSS shows a clear declining tendency from 1850 to 2100 (Fig. 1). Compared to the WOA09 observational data, most of the models are too fresh at the surface in the 1990s, especially the HadGEM2-ES, which has the lowest global mean SSS. The model spread is partly due to internal variability simulated by the climate models. Model 
Table 2. A brief description of the marine biogeochemical components included in the ESMs. Nutrients limiting phytoplankton growth, the number of explicit phytoplankton groups, the number of explicit zooplankton groups, representation of heterotrophic bacteria, the use of fixed (Redfield: $R$ ) or variable $(V)$ ratios for organic matter production, and $Q_{10}$ for temperature dependency of biogeochemical processes (autotrophic/heterotrophic) are indicated.

\begin{tabular}{|c|c|c|c|c|c|}
\hline Model & Nutrients & Phytoplankton & Zooplankton & Organic material ratio & $Q_{10}$ \\
\hline TOPAZ2 & $\begin{array}{l}5\left(\mathrm{NO}_{3}, \mathrm{NH}_{4}, \mathrm{PO}_{4},\right. \\
\left.\mathrm{SiO}_{4}, \mathrm{~F}_{\mathrm{e}}\right)\end{array}$ & $\begin{array}{l}3 \text { (diatom, eukaryotes, } \\
\text { small diazotrophs) }\end{array}$ & 1 & $\begin{array}{l}R(\mathrm{C}: \mathrm{N}) \\
V\left(\mathrm{P}, \mathrm{S}_{\mathrm{i}}, \mathrm{Chl}, \mathrm{F}_{\mathrm{e}}\right)\end{array}$ & 1.88 \\
\hline HAMOCC5.2 & $3\left(\mathrm{NO}_{3}, \mathrm{~F}_{\mathrm{e}}, \mathrm{PO}_{4}\right)$ & $\begin{array}{l}1 \text { (separated into } \\
\text { diatoms and calcifiers) }\end{array}$ & 1 & $R(\mathrm{C}: \mathrm{N}: \mathrm{P}: \mathrm{Fe})$ & 1.88 \\
\hline HAMOCC5.1 & $3\left(\mathrm{NO}_{3}, \mathrm{~F}_{\mathrm{e}}, \mathrm{PO}_{4}\right)$ & $\begin{array}{l}1 \text { (separated into } \\
\text { diatoms and calcifiers) }\end{array}$ & 1 & $R(\mathrm{C}: \mathrm{N}: \mathrm{P}: \mathrm{Fe})$ & 1.88 \\
\hline PISCES & $\begin{array}{l}5\left(\mathrm{NO}_{3}, \mathrm{~F}_{\mathrm{e}}, \mathrm{PO}_{4},\right. \\
\mathrm{NH}_{4}, \mathrm{SiO}_{4}\end{array}$ & $\begin{array}{l}2 \text { (diatoms and } \\
\text { nanophytoplankton) }\end{array}$ & $\begin{array}{l}2 \text { (micro and } \\
\text { meso) }\end{array}$ & $\begin{array}{l}R(\mathrm{C}: \mathrm{N}: \mathrm{P}) \\
\mathrm{V}\left(\mathrm{S}_{\mathrm{i}}, \mathrm{Chl}, \mathrm{F}_{\mathrm{e}}\right)\end{array}$ & $1.88 / 2.14$ \\
\hline Diat-HadOCC & $\begin{array}{l}4\left(\mathrm{NO}_{3}, \mathrm{~F} \text {, }\right. \\
\mathrm{NH}_{4}, \mathrm{SiO}_{4}\end{array}$ & $\begin{array}{l}2 \text { (diatoms and } \\
\text { nondiatom) }\end{array}$ & 1 & $\begin{array}{l}R(\mathrm{C}: \mathrm{N}) \\
\mathrm{V}\left(\mathrm{S}_{\mathrm{i}}, \mathrm{F}_{\mathrm{e}}\right)\end{array}$ & none \\
\hline BEC & $\begin{array}{l}5\left(\mathrm{NO}_{3}, \mathrm{NH}_{4}, \mathrm{PO}_{4},\right. \\
\left.\mathrm{SiO}_{4}, \mathrm{~F}_{\mathrm{e}}\right)\end{array}$ & $\begin{array}{l}3 \text { (diatom, nano-, } \\
\text { phyto, diazotrophs) }\end{array}$ & 1 & $\begin{array}{l}R(\mathrm{C}: \mathrm{N}: \mathrm{P}) \\
V\left(\mathrm{~S}_{\mathrm{i}}, \mathrm{Chl}, \mathrm{F}_{\mathrm{e}}\right)\end{array}$ & 2.0 \\
\hline
\end{tabular}

differences in physics, but also in spin-up procedures, the way RCP scenarios are set up and model climate sensitivities all likely contribute to the model spread (Knutti and Hegerl, 2008; Szopa et al., 2013).

Vertical density profiles help to further explain the changes in stratification. Mean vertical profiles of density in the 1990s and the density change between the 1990s and the 2090s show that all the models become more buoyant at the surface as a consequence of heating and/or freshening of the upper ocean (Fig. S1 in the Supplement). The density changes at the surface vary by almost a factor of 2 among models, from $-1.1 \mathrm{~kg} \mathrm{~m}^{-3}$ (HadGEM-ES2) to $-0.6 \mathrm{~kg} \mathrm{~m}^{-3}$ (GFDLES2M), but converge to a relatively narrow range (approximately $-0.2 \mathrm{~kg} \mathrm{~m}^{-3}$ ) at $500 \mathrm{~m}$ depth. Most of the density change occurs between the surface and $200 \mathrm{~m}$. Below $200 \mathrm{~m}$, the density change in most of the models varies linearly with depth. Thus, our definition of the stratification index, as the density difference between the surface and $200 \mathrm{~m}$, is reasonable. The converging reductions in density among models at about $500 \mathrm{~m}$ agrees with some previous studies based on observations and CMIP3 models (Bindoff et al., 2007; Lyman et al., 2010; Capotondi et al., 2012). Compared to WOA09 data, the models generally underestimate the density of the upper ocean in the top $150 \mathrm{~m}$ and most models overestimate the density below $350 \mathrm{~m}$ (resulting in a positive stratification bias) (Fig. S1a).

Vertical profiles of temperature and salinity from each model are also shown in Fig. S1. The surface ocean exhibits strong warming of $1.7-3.5^{\circ} \mathrm{C}$ by the $2090 \mathrm{~s}$ and the warming magnitude declines quickly with depth, which is associated with the heat uptake capacity of individual models. For instance, the GFDL models seem to be more efficient in transporting heat downward than the IPSL models. Above $300 \mathrm{~m}$, the temperature changes vary widely among the models. Temperature changes as a function of depth are complex, and model-to-model differences may be related to a number of factors including rates of vertical mixing and the seasonal thermocline dynamics. At the depth of $500 \mathrm{~m}$, the mean temperature change converges at about $1.2^{\circ} \mathrm{C}$. The ocean heat uptake capacity is linked to ocean diapycnal mixing and other processes, such as mixing by mesoscale eddies. The weak temperature gradients in the GFDL models suggest high rate of heat uptake, and are consistent with ocean heat uptake estimates by Kuhlbrodt and Gregory (2012). The large model spread in temperature profiles suggests considerable differences and uncertainties in the parameterizations of these physical processes across the models. Vertical profiles of salinity are more scattered than for temperature (Fig. S1c). In the 1990s, most of the models underestimate salinity from the surface down to $550 \mathrm{~m}$. Surface salinity is generally biased low by $0.05-0.25$ psu. Most of the freshening with climate change takes place above $100 \mathrm{~m}$, which also acts to increase stratification. Note that the salinity increases at 100 $300 \mathrm{~m}$ in some models (IPSL, GFDL-ESM2M, HadGEM2ES) partially compensates the impact of rising temperatures on density.

The percentage contribution of temperature change to the stratification change from the 1990s to the 2090s is shown in Fig. S2. Previous studies have shown that salinity contributes significantly to the stratification changes at high latitudes $\left(>40^{\circ}\right)$ in both hemispheres and in the North Pacific as a consequence of increases in precipitation (Bindoff et al., 2007). From our comparisons, temperature dominates the stratification changes in the tropical and subtropical regions (Fig. S2). Salinity dominates the stratification changes in the much of the Arctic Ocean and in the high-latitude North Atlantic. While stratification is a function of SSS and SST to a good approximation (Cabré et al., 2015), stratification change at high latitudes is also dependent on temperature and salinity at depth as vertical mixing and exchange are stronger. 
In some regions, the spatial distributions and the driving process differs substantially across models. Generally, the models agree well in the tropics and in the subtropical gyres that surface warming drives the increase of stratification. In the high-latitude North Atlantic, the subpolar Pacific and the western Pacific Ocean, there is weaker agreement across the models. In the subtropical gyre of the South Pacific, stratification changes in the IPSL and CESM1(BGC) models have a stronger influence from temperature change, while the other models exhibit more complicated spatial patterns. In the North Atlantic, salinity contributes more in the IPSL and HadGEM2 models than in the other models. The southeastern Pacific is more dominated by salinity in the two GFDL models. In the Southern Ocean, the models show relatively large contributions from both salinity and temperature but with complicated spatial patterns that differ considerably across models. Projections for the regions where the models do not agree even on the driving factor should be viewed with more caution. Climate change and biogeochemical impacts in these regions tend to be projected with less consistency across models (Bopp et al., 2013; Cabré et al., 2015).

Stratification increases globally in all the models with climate change (Figs. 1 and 2). Nearly all the models predict large increases in stratification in the western tropical Pacific, the tropical Indian Ocean, the Arctic Ocean and in the highlatitude North Atlantic (particularly in the Labrador Sea). The Southern Ocean has weaker increases in stratification, partly because the surface layer mixing and upwelling are intensified due to the poleward shift of strengthened westerly jets (Swart and Fyfe, 2012). Our stratification index may underestimate the changes in the high-latitude North Atlantic, as the relatively deep mixing means that temperature and salinity at $200 \mathrm{~m}$ depth are changing much more rapidly than in other regions. Reductions in the deep winter mixing and NADW formation in this region are a common pattern seen in strong warming climate simulations (e.g., Cheng et al., 2013; Schwinger et al., 2014). Less drastic increases in stratification are seen over much of the rest of the oceans, with only a few small regions showing decreases in some models. An exception is the HadGEM2-ES model, which has large stratification reductions in the Arctic (Fig. 2).

\subsection{Surface nutrient trends with climate change}

One of the key factors determining global NPP is nutrient availability in the euphotic zone. Time series of global mean nutrient $(0-100 \mathrm{~m})$ concentrations for nitrate $\left(\mathrm{NO}_{3}\right)$, phosphate $\left(\mathrm{PO}_{4}\right)$, silicic acid $\left(\mathrm{SiO}_{4}\right)$ and dissolved iron $(\mathrm{dFe})$ are presented in Fig. 3. The magnitude of surface nutrient concentrations differs substantially across the models (varying by a factor of $\sim 1.5-2$, and by a factor of 5 for dissolved iron). The IPSL models have relatively low surface nutrient concentrations. Compared to the WOA09, two models overestimate phosphate (CESM1(BGC) and GFDL-ESM2G) and five models overestimate nitrate. All of the models over- estimate the silicic acid observations, with the exception of CESM1(BGC). The CESM1(BGC) model overestimates surface phosphate concentrations initially, due to excessive nitrogen limitation, but then shows the strongest surface phosphate declines over the 21 st century (Fig. 4).

Over the entire period from 1850-2100, the models all display decreasing trends for surface nitrate, phosphate and silicic acid. Interestingly, surface iron concentrations increase modestly in all but one of the models by $4-10 \%$. Changes in iron concentrations impact marine productivity, nitrogen fixation rates and oceanic net $\mathrm{CO}_{2}$ uptake. In the CMIP5 simulations, iron inputs to the oceans from deposition and rivers are held constant over time, so the increasing surface iron concentrations may reflect increasing macronutrient limitation of phytoplankton growth, leading to reduced biological uptake of iron. The reductions in the sinking export flux also reduce the particle scavenging loss term for dissolved iron. In the CESM1(BGC) model, increased production in the highnutrient, low-chlorophyll (HNLC) regions offset about $25 \%$ of the reduction observed in the macronutrient-limited areas with climate change, and changing circulation patterns also altered the lateral transport of iron within the oceans (Moore et al., 2013; Misumi et al., 2014).

The relative changes in nutrient concentrations $(0-100 \mathrm{~m})$ (normalized to 1990s means) are presented in Fig. 4. The relative changes in the historical run show a consistent pattern across the models for nitrate, phosphate and dissolved iron (except for HadGEM2-ES). In the RCP8.5 projection, the models show diverging estimates of the magnitude of the relative changes. For nitrate, the reductions range between 3 and $14 \%$, whereas for phosphate the reductions range between 3 and $20 \%$. Silicic acid and iron trends are even more variable than for nitrate and phosphate. For silicic acid, three models exhibit slight increases, while the others exhibit decreases ranging from $5-17 \%$. The variability in relative change in silicic acid concentration in the RCP8.5 is likely associated with changes in plankton community and variable diatom production (Bopp et al., 2005). All of the models include some representation of diatoms (Table 2) but the match to observed silicic acid concentrations for the current era is generally poor (Fig. 3).

The spatial distributions of mean nitrate concentration for 0-100 $\mathrm{m}$ in the 1990s are shown in Fig. S3. The CMIP5 models reproduce key observed features of the basin-scale distributions of surface nitrate. For example, all of the models exhibit elevated nitrate concentrations in the eastern equatorial Pacific, Southern Ocean, subarctic North Atlantic and subarctic Pacific. In the subtropical gyres of the Atlantic and $\mathrm{Pa}-$ cific basins, mean nitrate concentrations are low. These general patterns are consistent with the WOA09 observations. However, there are clear disagreements in some regions. For example, the details of the high-nitrate surface water distributions vary considerably in the eastern equatorial Pacific. The HNLC condition extends too far north and south of the equator in some models, and too far to the west in others 

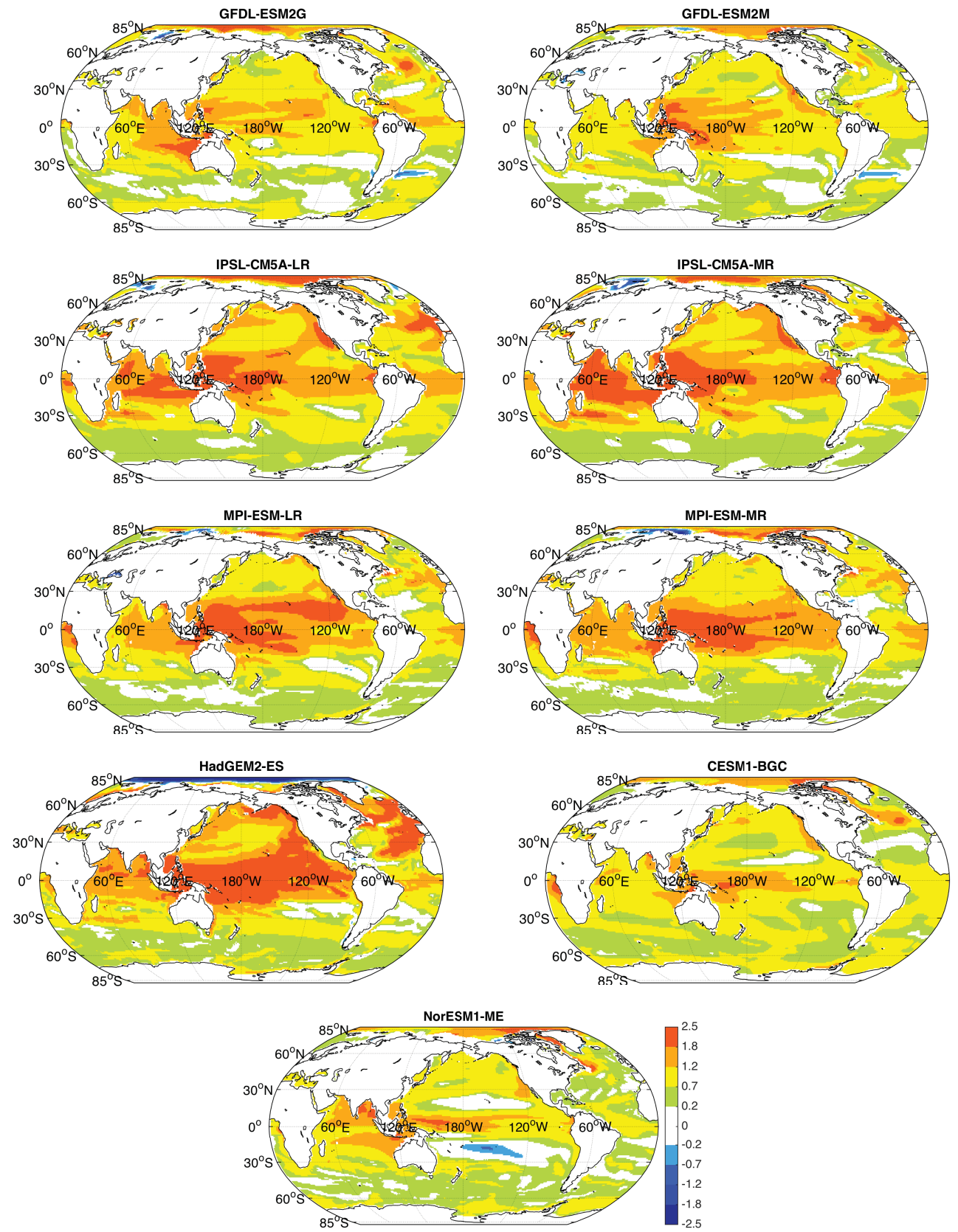

Figure 2. The spatial pattern is shown for changes in stratification between the 1990s and the 2090s.

(Fig. S3). The models also differ in the intensity and extent of high nitrate concentration waters in the subarctic North Pacific, where six of nine models show lower nitrate concentrations than the WOA09 data (MPI-ESM-LR, MPI-ESM-MR and HadGEM2-ES are closest to the observations). There are also differences in the Arabian Sea and Bay of Bengal, where most models underestimate nitrate concentrations except the GFDL-ESM2M and MPI-ESM-LR models.

Intermodel spread in NPP during the 1990s is pronounced, with NPP as low as $29 \mathrm{PgC} \mathrm{yr}^{-1}$ (IPSL-CM5A-LR and IPSL-
CM5A-MR), while NPP in one model exceeds $75 \mathrm{PgC} \mathrm{yr}^{-1}$ (GFDL-ESM2M) (Table 3, Fig. 5). In addition, the spatial pattern of NPP is not well represented by the multimodel mean (Bopp et al., 2013). Satellite-based estimation of NPP is approximately $50 \mathrm{PgC} \mathrm{yr}^{-1}$ (Behrenfeld et al., 2006; Carr et al., 2006). The MPI-ES-MR and CESM1(BGC) models had NPP of 49.8 and $54.2 \mathrm{PgC} \mathrm{yr}^{-1}$, closer to the satellitebased estimates and the observationally constrained, model estimate of $56 \mathrm{PgC} \mathrm{yr}^{-1}$ by Buitenhuis et al. (2013). The 


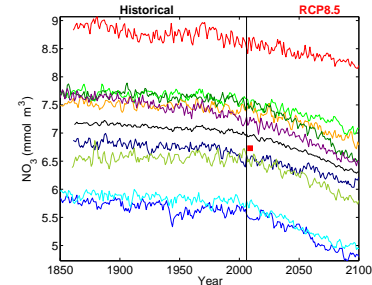

(a) $\mathrm{NO}_{3}$

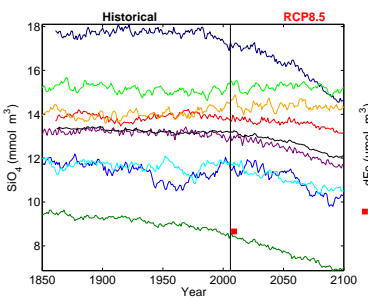

(c) $\mathrm{SiO}_{4}$

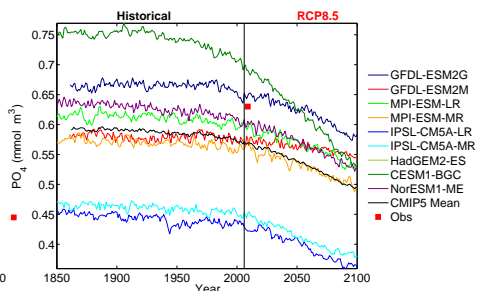

(b) $\mathrm{PO}_{4}$

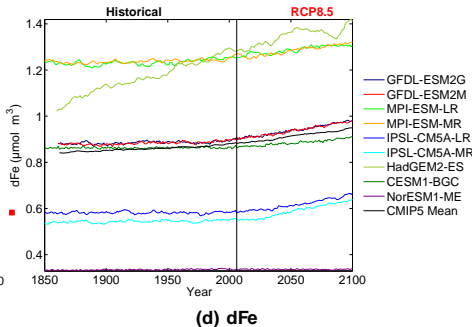

(d) $\mathrm{dFe}$
Figure 3. Time series of nitrate $\left(\mathrm{NO}_{3}\right)$, phosphate $\left(\mathrm{PO}_{4}\right)$, silicate $\left(\mathrm{SiO}_{4}\right)$ and dissolved iron $(\mathrm{dFe})$ concentrations $(0-100 \mathrm{~m})$ are shown for 1850-2100. Red square indicates WOA2009 global mean values.

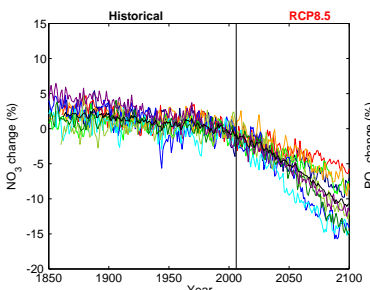

(a) NO3 change

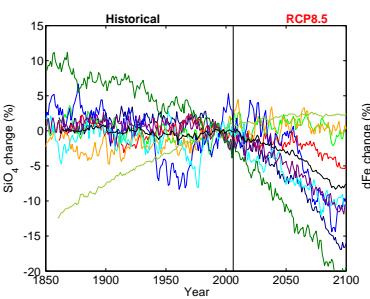

(c) $\mathrm{SiO} 4$ change

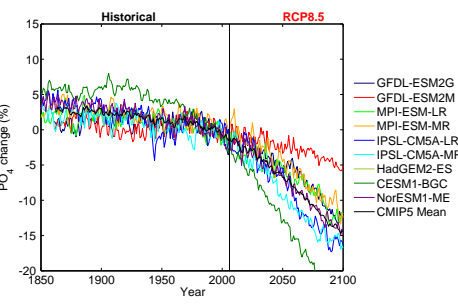

(b) $\mathrm{PO}$ change

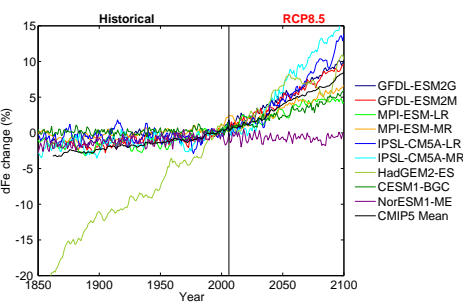

(d) dFe change
Figure 4. Time series are displayed of mean changes (in percent) relative to the 1990 s for (a) $\mathrm{NO}_{3}$, (b) $\mathrm{PO}_{4}$, (c) $\mathrm{SiO}_{4}$ and (d) $\mathrm{dFe}$ (0-100 m) during 1850-2100.

magnitude of EP also varies substantially across models in the $1990 \mathrm{~s}$, ranging from 4.4 to $7.2 \mathrm{PgC} \mathrm{yr}^{-1}$ (Table 3).

\subsection{Climate change impacts on NPP and EP}

All of the models exhibit decreasing trends in global NPP and EP with climate change, as shown in previous studies (Bopp et al., 2013; Dutkiewicz et al., 2013) and most models show more rapid decreases during the middle to latter part of the 21st century (Figs. 5-6, Table 3). All nine models project decreases in export production by the 2090s, exceeding $5 \%$ relative to levels in the 1990s, whereas the

\begin{tabular}{|c|c|}
\hline 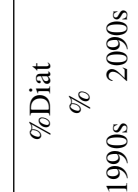 & 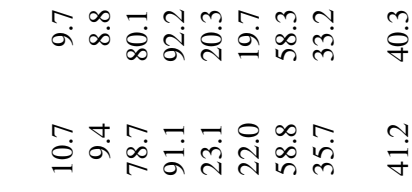 \\
\hline 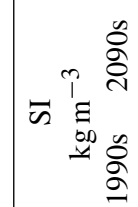 & 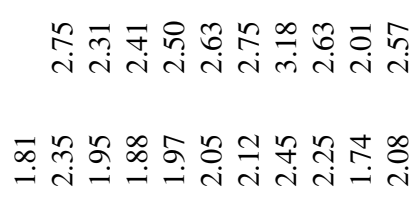 \\
\hline 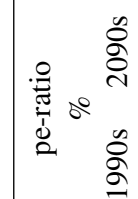 & 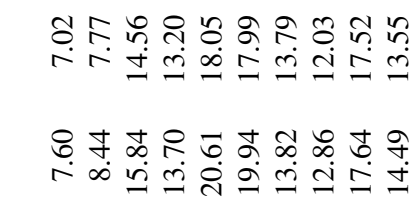 \\
\hline 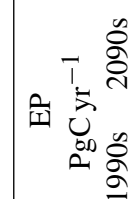 & 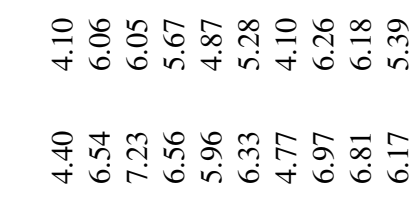 \\
\hline 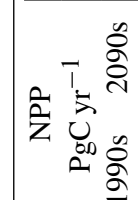 & 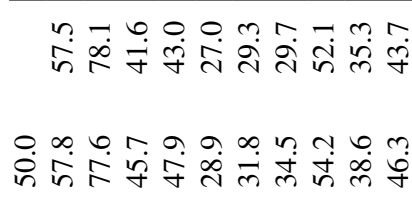 \\
\hline 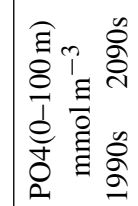 & 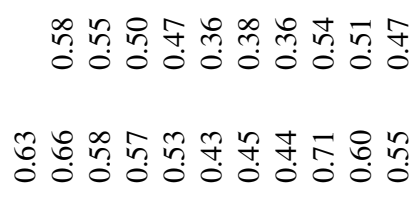 \\
\hline 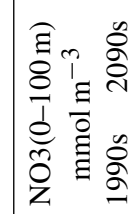 & 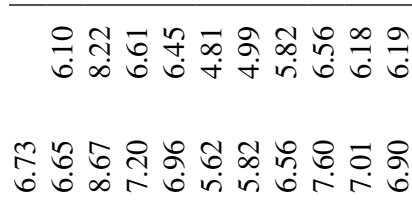 \\
\hline 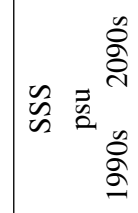 & 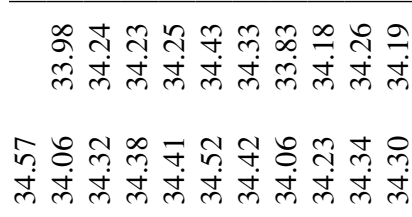 \\
\hline 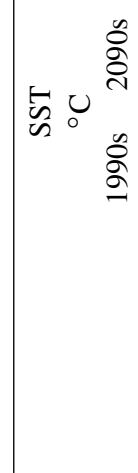 & 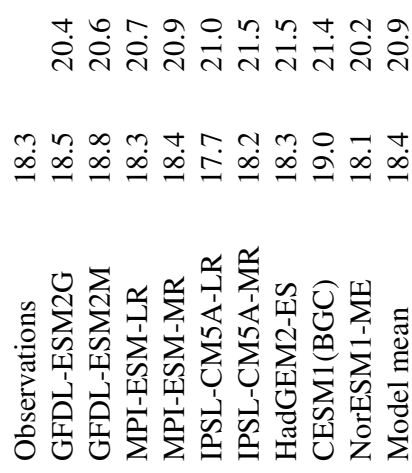 \\
\hline
\end{tabular}

Biogeosciences, 13, 5151-5170, 2016 


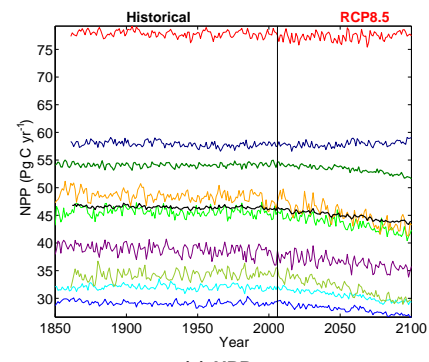

(a) NPP

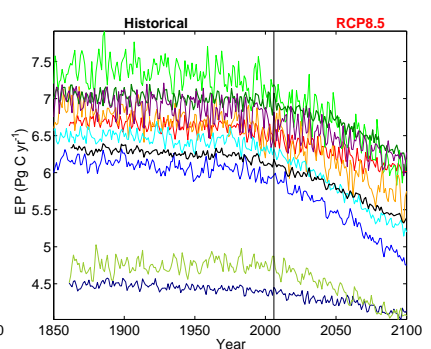

(b) EP

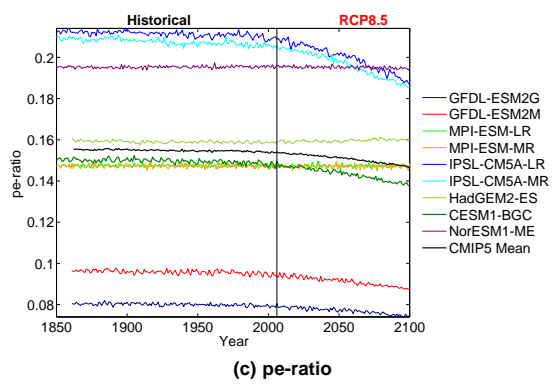

Figure 5. Time series of global mean net primary production, export production and the particle export ratio over 1850-2100 are shown for each model.

response for NPP is divided into two groups after 2020 . The CESM1(BGC) and GFDL models experience smaller changes in NPP $(<5 \%$ relative to 1990 s) while other models have larger decreases $(8-16 \%)$. The largest relative change for NPP is about $-16 \%$ (MPI-ESM-LR). The EP decreases range from $7 \%$ for GFDL-ESM2G to $28 \%$ for IPSL-CM5ALR. Cabré et al. (2015) found reductions in NPP and EP for all biomes, except at the highest latitudes. The reductions in global NPP and EP covary with the increases in stratification (Fig. 6). By the 2090s, stratification increases by about $16 \%$ in GFDL-ESM2M and up to $33 \%$ in HadGEM1-ES. The rate of stratification increase is slower in the two GFDL models and CESM1(BGC), which also agrees with the slower rates of relative NPP and EP change.

The variability across models in NPP is substantially larger than that seen in EP (Table 3). The normalized standard deviation was $\pm 27 \%$ for NPP, but only $\pm 12 \%$ for EP in the 1990s. The large spread in simulated NPP and its response to climate change was also noted by (Laufkötter et al., 2015). Seven of the nine models have an EP between 6.0 and $7.2 \mathrm{PgC} \mathrm{yr}^{-1}$ in the $1990 \mathrm{~s}$, with the remaining two (HadGEM2-ES and GFDL-ESM2G) having considerably lower $\mathrm{EP}\left(<5 \mathrm{PgC} \mathrm{yr}^{-1}\right)$. $\mathrm{EP}$ is tightly coupled to new nutrient inputs to the euphotic zone in these models. NPP is less tightly coupled as the fraction of regenerated production varies across the models, and can vary spatially and temporally within some models. Thus, the large spread in NPP is not just a function of the different physical models and their transport of nutrients to the euphotic zone, but rather it is also strongly impacted by the phytoplankton community structure

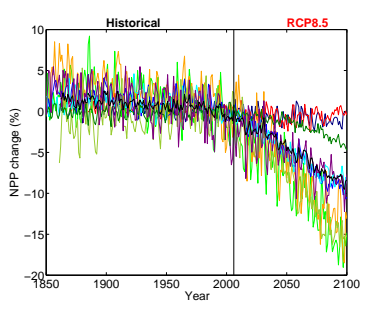

(a) NPP change

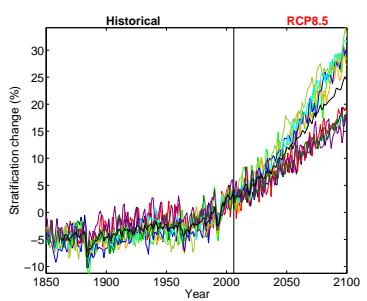

(c) SI change

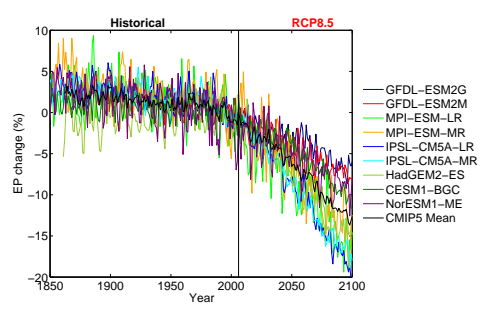

(b) EP change

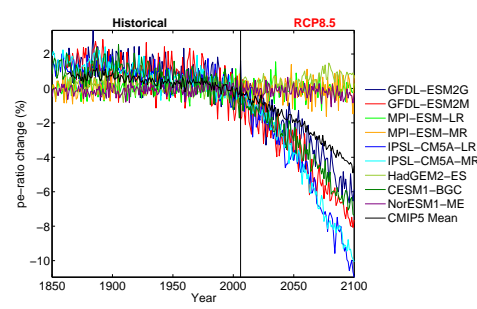

(d) pe-ratio change
Figure 6. Time series are displayed of the percent changes in net primary production, export production and the particle export ratio and stratification over the period 1850-2100 (each relative to their 1990s means).

and export efficiency inherent in the models, and the resulting varying levels of regenerated production.

The sinking carbon flux out of the euphotic zone to net primary production ratio (particle export ratio or pe-ratio) is a measure of the export efficiency and also reflects the variable contribution of regenerated production to total NPP (Dugdale and Goering, 1967; Eppley and Peterson, 1979; Dunne et al., 2007). High pe-ratio values are typically associated with productive ecosystems dominated by larger phytoplankton (often diatoms; Buesseler, 1998; Boyd and Newton, 1999), while low pe-ratios are associated with oligotrophic food webs with most carbon flow through the microbial loop (Pomeroy, 1974; Azam et al., 1983). The CMIP5 models that include both large and small phytoplankton, assume a higher export efficiency for the large phytoplankton (Aumont and Bopp, 2006; Seferian et al., 2013; Tjiputra et al., 2013). The fraction of grazed material routed to sinking export is higher, often by a factor of 3 or more, than the fraction routed to sinking export for the small phytoplankton. Diatoms are also likely to dominate phytoplankton blooms in these models. This can drive additional, very efficient, export through aggregation, further enhancing the differences in export efficiency between large and small phytoplankton. Relative to the 1990s, six of the nine models show decreasing trends in the pe-ratio (up to a 10\% reduction) (Figs. 5-6, Table 3; see also Cabré et al., 2015). Diatoms account for a smaller percentage of NPP in the 2090s than in the 1990s in all the models, except for the MPI model, where nearly all of the production is by diatoms and the smallest phytoplankton are not explicitly represented (Table 3 ). 


\subsection{Increasing stratification and declining nutrients, NPP and EP}

We quantify the relations between stratification and key biogeochemical variables with annual model output over the entire time period of 1850-2100. This approach captures physical-biological interactions over interannual to centennial timescales, and is thus more robust than the earlier work comparing two end points from the beginning and end of the 21st century (Bopp et al., 2013; Cabré et al., 2015). Changes in global NPP relative to the 1990s are plotted against the relative change in stratification in Fig. 7a. Across all the ESMs, a relatively good relationship exists with a correlation $r^{2}=0.72$. Larger relative increases in stratification correspond to larger relative declines in NPP. In addition, the globally fitted line with a slope of 0.38 separates the models into two groups. In one group (GFDL, IPSL and CESM1(BGC)), the NPP reductions are more modest as stratification increases; the other group is composed of the two MPI models, HadGEM1-ES and the NorESM model, which show more intense and linear reductions in NPP with increasing stratification. The reduction of NPP can be partly explained by nutrient changes responding to stratification increases. Across the models, surface nitrate and phosphate concentrations clearly decline as the stratification is enhanced (Fig. 7c and d, with $r^{2}$ of 0.80 and 0.82 , respectively). Note that all of these trends are robust across the full time series. Compared to the 1990s, the preindustrial stratification is weaker, surface nutrient concentrations are higher, and NPP and EP are elevated (Figs. 37).

This indicates significant climate change impacts on ocean biogeochemistry, prior to the 1990s and the modern era when most ocean observations have been made. The response of surface silicic acid to increasing stratification is more variable. The projected changes are more divided, as three models (MPI-ESM-LR, MPI-ESM-MR and HadGEM1-ES) show slight increases and the others show reductions in surface silicic acid concentrations (Fig. 7b).

$\mathrm{EP}$ is even more closely related to the stratification changes $\left(r^{2}=0.89\right)$ than NPP $\left(r^{2}=0.72\right.$; Fig. 7e $)$. The EP change is also closely related to the NPP change $\left(r^{2}=0.85\right)$. EP decreases by up to $20 \%$ (Fig. 7e), whereas NPP decreases by $10-18 \%$. The models display two patterns in terms of the response of NPP and EP to climate change. The first group includes five models (the two IPSL models, CESM1(BGC) and the two GFDL models) where the relative declines in NPP are smaller than the relative declines in EP by a factor of 2 or more (Fig. 6 and Table 3). In this group, the EP drops by about $10 \%$ and the NPP decreases by $5 \%$. In the remaining models, the relative declines in EP and NPP are larger and more similar in magnitude. For example, both EP and NPP decrease by about $14 \%$ in the HadGEM2-ES model. The differential declines in NPP and EP in the first group of models documents declining export efficiency for the ocean biological pump, driven by phytoplankton community shifts

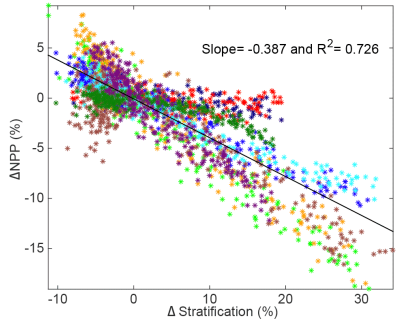

(a) $\triangle \mathrm{SI}$ vs. $\triangle \mathrm{NPP}$

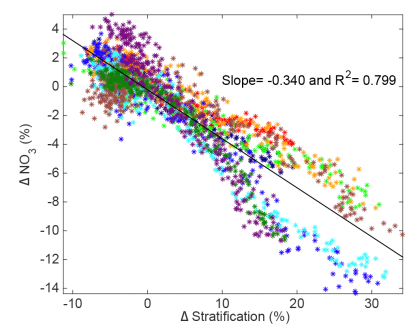

(c) $\Delta$ SI vs. $\Delta \mathrm{NO}_{3}$

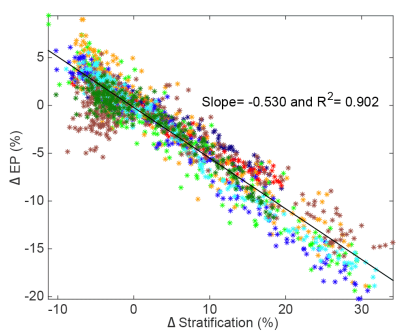

(e) $\Delta$ SI vs. $\Delta \mathrm{EP}$

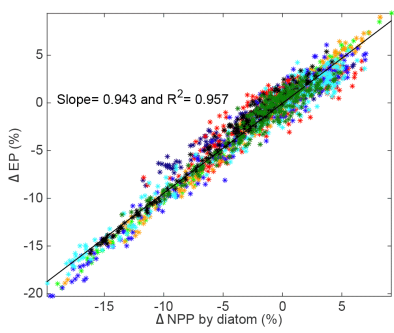

(g) $\triangle$ NPP by diatom vs. $\triangle \mathrm{EP}$

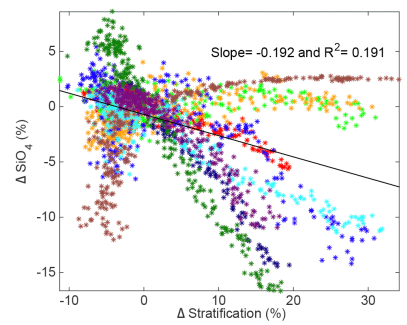

(b) $\Delta \mathrm{SI}$ vs. $\Delta \mathrm{SiO}_{4}$

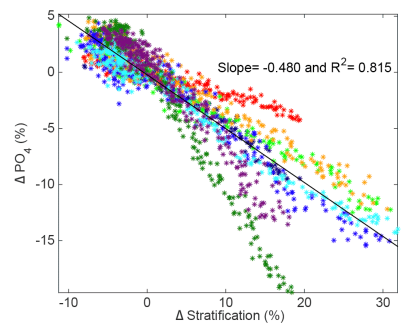

(d) $\Delta \mathrm{SI}$ vs. $\Delta \mathrm{PO}_{4}$

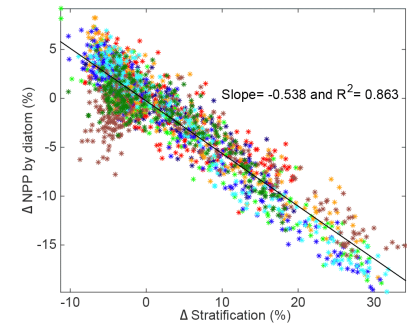

(f) $\triangle \mathrm{SI}$ vs. $\triangle \mathrm{NPP}$ by diatom

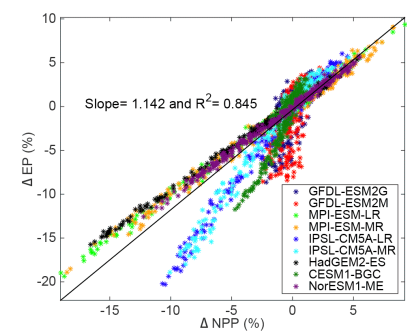

(h) $\triangle \mathrm{NPP}$ vs. $\triangle \mathrm{EP}$
Figure 7. Relationships are shown between the relative percent change in surface stratification with climate and the relative change in several biogeochemical variables including net primary production (NPP) (a), silicate (b), nitrate (c), phosphate (d), export production (EP) (e), the fraction of NPP by diatoms (f). EP is plotted against the change in the fraction of NPP by diatoms (g) and against the change in NPP (h). All changes are relative to the 1990s and plotted over 1850-2100. These time series are derived from global annual mean data.

and a decreased contribution to NPP by large phytoplankton (diatoms) (see below and Figs. 6-10; also Cabré et al., 2015).

Reduced nutrient availability is a major contributor to the declines in NPP and EP. However, the relationship varies from one model to another because growth and export are complicated functions of macronutrient limitation, tempera- 

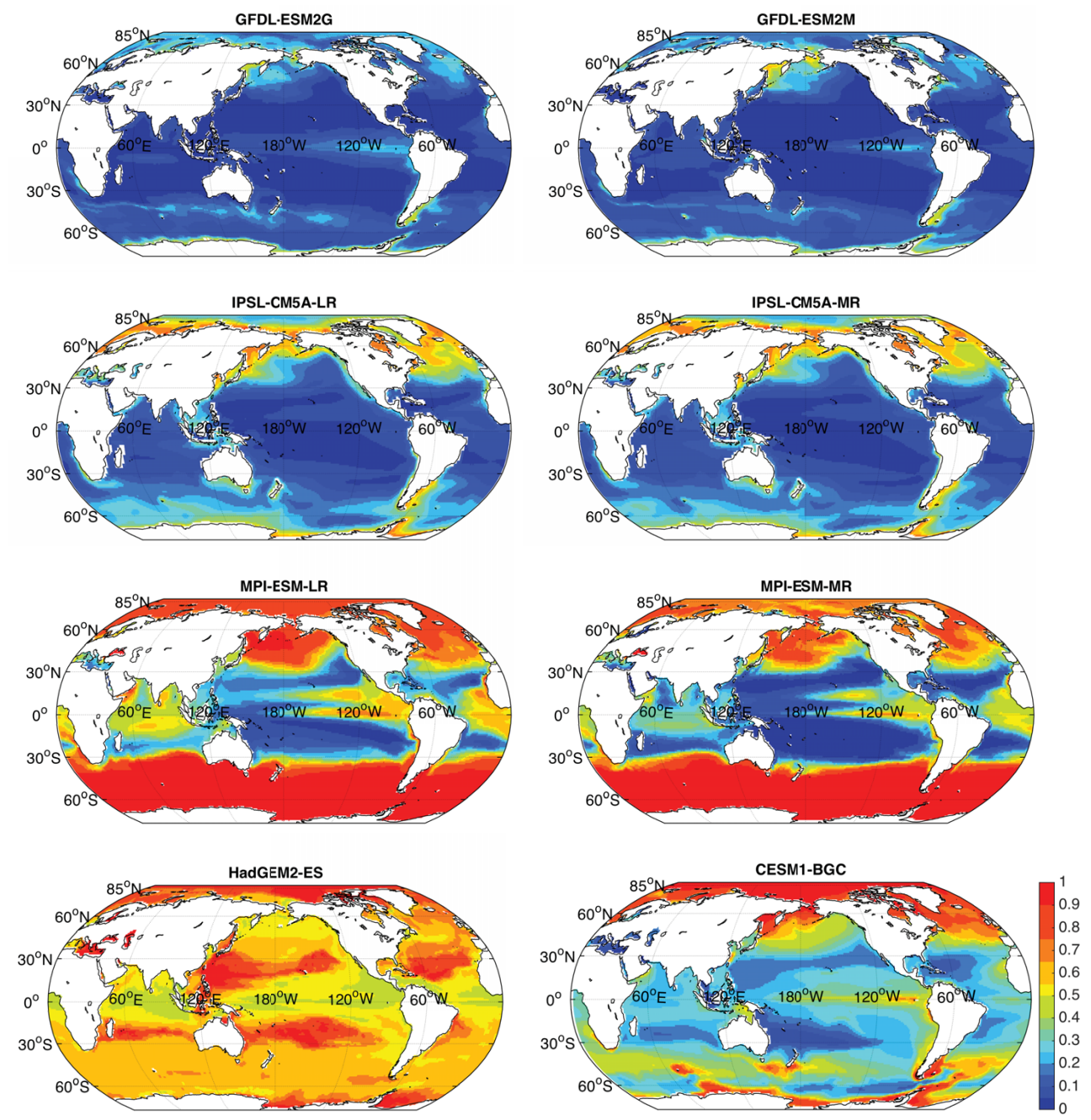

Figure 8. The fraction of total NPP by diatoms for the 1990s is shown for each model (data for NorESM not available).

ture, irradiance and iron limitation, as well as the routing of organic matter within the ecosystem that drives export efficiency. Higher metabolic rates with warming can be compensated to a large degree by changes in the supply of nutrients in terms of globally integrated productivity (Dutkiewicz et al., 2013). The NPP response is also strongly impacted by phytoplankton community structure, which modifies export efficiency, and the corresponding magnitude of regenerated primary production. For the IPSL, CESM1(BGC) and GFDL models that show larger declines in EP than in NPP, this pattern is driven by a decreasing contribution to total NPP by large phytoplankton (Table 3, Figs. 8-9). Most of the primary production in these models is by smaller phytoplankton. The GFDL models express this pattern most strongly, with minimal declines in NPP, despite declines in EP approaching $10 \%$ (Fig. 6 and Table 3). The other models tend to have production that is dominated by diatoms, and do not capture the community shifts towards increasing small phytoplankton dominance (and reduced export efficiency) under increas- ing nutrient stress. The declines in NPP with increasing stratification are more linear and more similar in magnitude to the declines in EP (Fig. 7a, b and h). Thus, there are also very strong correlations between the climate-driven changes in the fractional contribution of diatoms to NPP and both the changes in stratification and the changes in EP (Fig. 7f and $\mathrm{g}$, correlations of $r^{2}=0.85$ and $r^{2}=0.95$, both much higher than the correlation between changing stratification and NPP, $\left.r^{2}=0.71\right)$. Cabré et al. (2015) found similar patterns relating community composition, NPP and EP comparing the period of 1980-1999 with 2080-2099, across low to midlatitude biomes.

Some of these patterns are illustrated in Fig. 8, which shows the contribution of diatoms (large phytoplankton) to NPP for the 1990s. Most of the models show elevated diatom production at high latitudes and low diatom contributions in the subtropical gyres. However, there are large discrepancies in the magnitude of the diatom contribution, ranging from about $30 \%$ to more than $90 \%$ in the Arctic Ocean, for ex- 

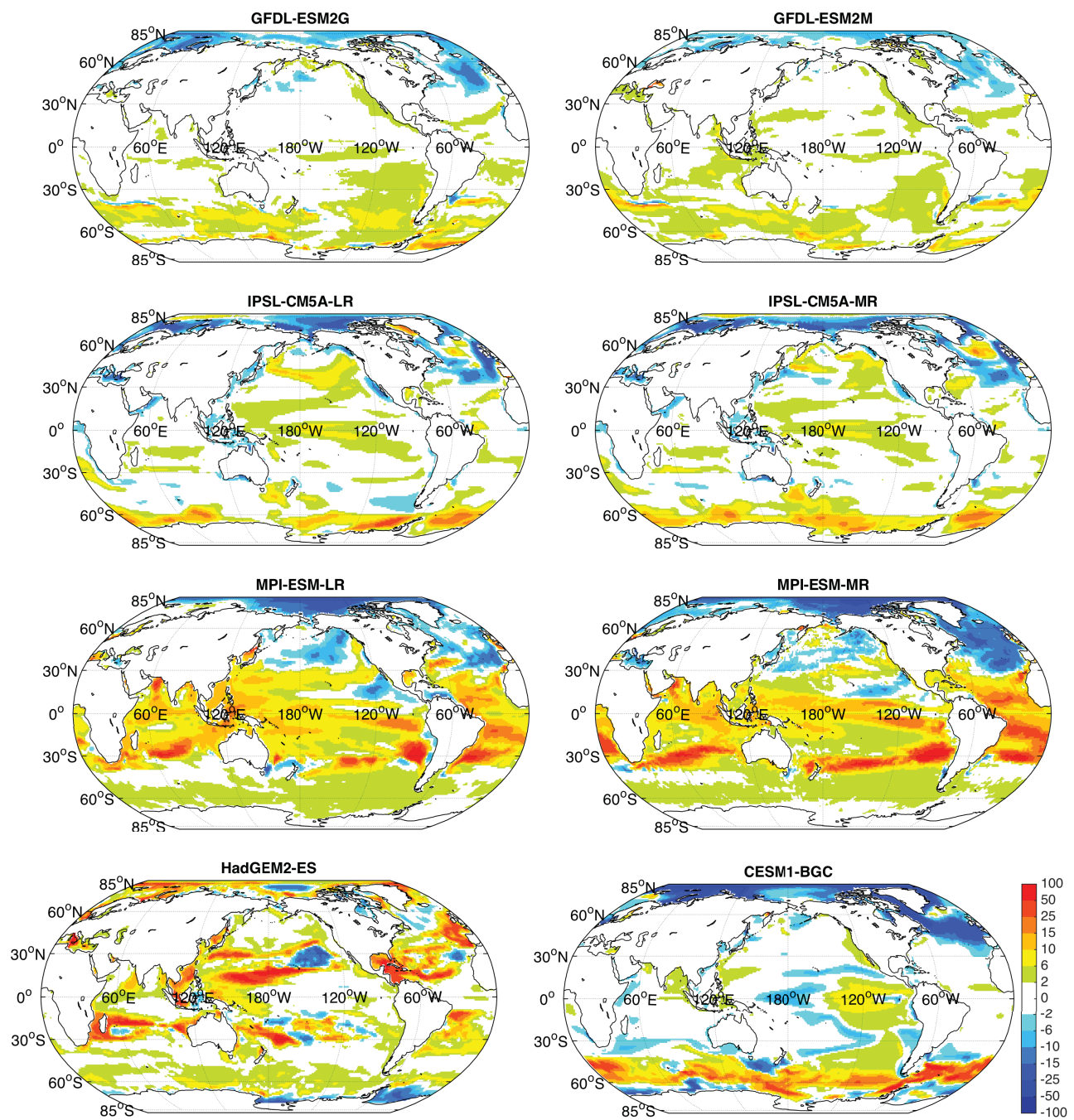

Figure 9. The percent change in NPP by diatoms between the 2090s and the 1990s.

ample. At the global scale, diatoms account for only $9.4 \%$ of NPP in the GFDL-ESM2M model and reach a maximum of $91 \%$ in the MPI-ESM-MR model (Table 3). The large variability across the models reflects, in part, the lack of observational data sets to constrain phytoplankton community composition at the time these models were being developed. The new globally gridded ocean atlas of plankton functional types, Marine Ecosystem Data (MAREDAT) (Buitenhuis et al., 2013) has started to fill this gap, and should lead to improved representations of plankton community structure in the future as the data set becomes increasingly populated and is entrained into model development and validation. Remote sensing estimates of phytoplankton community composition and size class structures are also providing useful constraints for global-scale modeling efforts (e.g., Alvain et al., 2005; Hirata et al., 2008; Kostadinov et al., 2009; Siegel et al., 2014).
The spatial patterns of the shifts in phytoplankton community composition with climate change are illustrated in Figure 9; which shows the change in the percentage of NPP by diatoms (2090s-1990s). There are some robust trends across the models. One of the areas with the biggest declines in diatom production is the high-latitude North Atlantic. This region typically has some of the biggest stratification increases with climate change, greatly reducing the deep winter mixing that entrains nutrients to the surface (Moore et al., 2013; Randerson et al., 2015). Nearly all the models also show large declines in diatom contributions to production in the Arctic Ocean. The CMIP5 models show consistent trends of increasing stratification, declining surface nutrient concentrations and a longer growing season with climate change in the Arctic (Vancoppenolle et al., 2013). Increasing surface temperatures and substantial declines in sea ice cover allow for a longer growing season with climate change. Thus, nutrients in surface waters are more completely used up by summer's 
end, leading to community shifts with decreased diatom production and an increased fraction of production by smaller phytoplankton. In the CESM1(BGC) model, this community shift allows for a small increase in central Arctic NPP, even as export production and surface nutrient concentrations decline, due to the increased fraction of NPP from small phytoplankton and the resulting increases in regenerated production (Moore et al., 2013).

All of the models show some increase in the fraction of NPP by diatoms in the Southern Ocean (Fig. 9). The increase is particularly strong in the CESM1(BGC), IPSL and GFDL models. Most of the models also show some increased diatom production in the tropical Pacific. Bopp et al. (2005) reported decreasing diatom production in the Arctic and high-latitude North Atlantic, with some increases in the Southern Ocean under a strong warming climate scenario. Steinacher et al. (2010) also found declining productivity in the North Atlantic and shifts in the export ratio due to phytoplankton community shifts with decreasing diatom production. An earlier version of the CESM used in that study (CCSM3) showed only small shifts in export ratios with climate change, as the range in export ratios and the differences in export efficiencies between large and small phytoplankton were smaller than in CESM1(BGC) (Steinacher et al., 2010; Moore et al., 2013). Three models in this study (HadGEM2ES and the two MPI models) show increases in diatom production in the low latitudes (Fig. 9). However, the diatoms dominate production nearly everywhere in these three models (Fig. 8).

There are also large intermodel differences in the spatial patterns of the pe-ratio (Fig. 10). Some of the models (GFDL, IPSL, CESM1(BGC)) show a close correlation between the pe-ratio and diatom production (compare Figs. 8 and 10), due to the enhanced export efficiency for diatoms (large phytoplankton) built into the models. Thus, there is a very high correlation between the changing contribution of diatoms to NPP and the changes in EP (Fig. 7g, Table 3). The MPI model includes one phytoplankton group and has an essentially constant pe-ratio of 0.15 , explaining the linearity of the changes in NPP and EP with warming (Figs. 8 and 10). Production in the HadGEM1-ES model is dominated nearly everywhere by the diatoms (Fig. 8). Therefore, the MPI and HadGEM models cannot capture a shift towards increasing small phytoplankton dominance under declining surface nutrient concentrations. This leads to export production being closely correlated with diatom production in these models as most production is by diatoms, as well as in the other models where diatoms are assumed to export more efficiently but account for a smaller fraction of total NPP (Table 3).

There is also a strong correlation between the declines in the fraction of NPP by diatoms and declines in the pe-ratio (compare Figs. 7, 9 and 11). The largest declines in the peratio are seen in the Arctic and the high-latitude North Atlantic, regions where diatom production also decreases the most. The GFDL, IPSL and CESM1(BGC) models show some reductions in pe-ratio in the subarctic North Pacific, but the spatial patterns are inconsistent (Fig. 11). The models display considerable variability in the degree of stratification increase and in the dominant factor driving these changes in the subarctic North Pacific (Figs. S2 and 2).

The correlation for the relationship between the changing percentage of NPP by diatoms vs. the changes in EP across all the models has an $r^{2}$ of 0.96 and a slope close to $1(0.94$, Fig. 7g), indicating that phytoplankton community structure plays a dominant role in determining the responses of NPP, $\mathrm{EP}$ and the pe-ratio to climate change. The biggest declines in the fraction of production by diatoms and pe-ratios are in precisely the areas where some of the largest increases in upper ocean stratification are seen, along with declining surface nutrient concentrations, as in the Arctic Ocean and in the high-latitude North Atlantic (Figs. 6-8; see also Steinacher et al., 2010; Moore et al., 2013).

\subsection{Projected changes in NPP, EP and stratification biases}

At the global scale, the CMIP5 models show considerable stratification biases for the 1990s when compared to the WOA09 data (Fig. 1, Table 3). Only the GFDL-ESM2M model is within $10 \%$ of the observed value. From the density profiles as well (Fig. S1), it is apparent that most of the models have stronger stratification in the 1990s than seen in the observations. Liu et al. (2014) argue that climate bias is important when projecting the impact of climate change on land surface processes and Hoffman et al. (2014) document this for atmospheric $\mathrm{CO}_{2}$ mole fractions. Here, we examine how stratification biases in the 1990s may affect model projections of NPP and EP in the 2090s.

Models with stronger bias in the 1990s for surface stratification tend to predict larger climate-induced declines in both NPP and EP (Fig. 12, $r^{2}=0.47$ and $r^{2}=0.54$, respectively). The slopes are plotted when the correlation is significant at $>95 \%$ level. Five of the models have positive biases in stratification for the current era that exceed $20 \%$. These models also show the largest relative increases in stratification with climate change of $26-30 \%$ (Fig. 12, Table 3). The remaining four models (GFDL models, CESM1(BGC) and NorESM1-ME) do a better job of simulating observed stratification for the current era and predict relative increases in stratification over the 21 st century that are roughly half as large, ranging $\sim 15-18 \%$. This suggests that the more biased models (for the 1990s) may be overestimating the projected reductions in NPP and EP for the end of the century.

\section{Discussion and conclusions}

The ESMs analyzed here have different resolutions and incorporate marine biogeochemical-ecosystem models with different mechanisms and degrees of complexity. We find this 

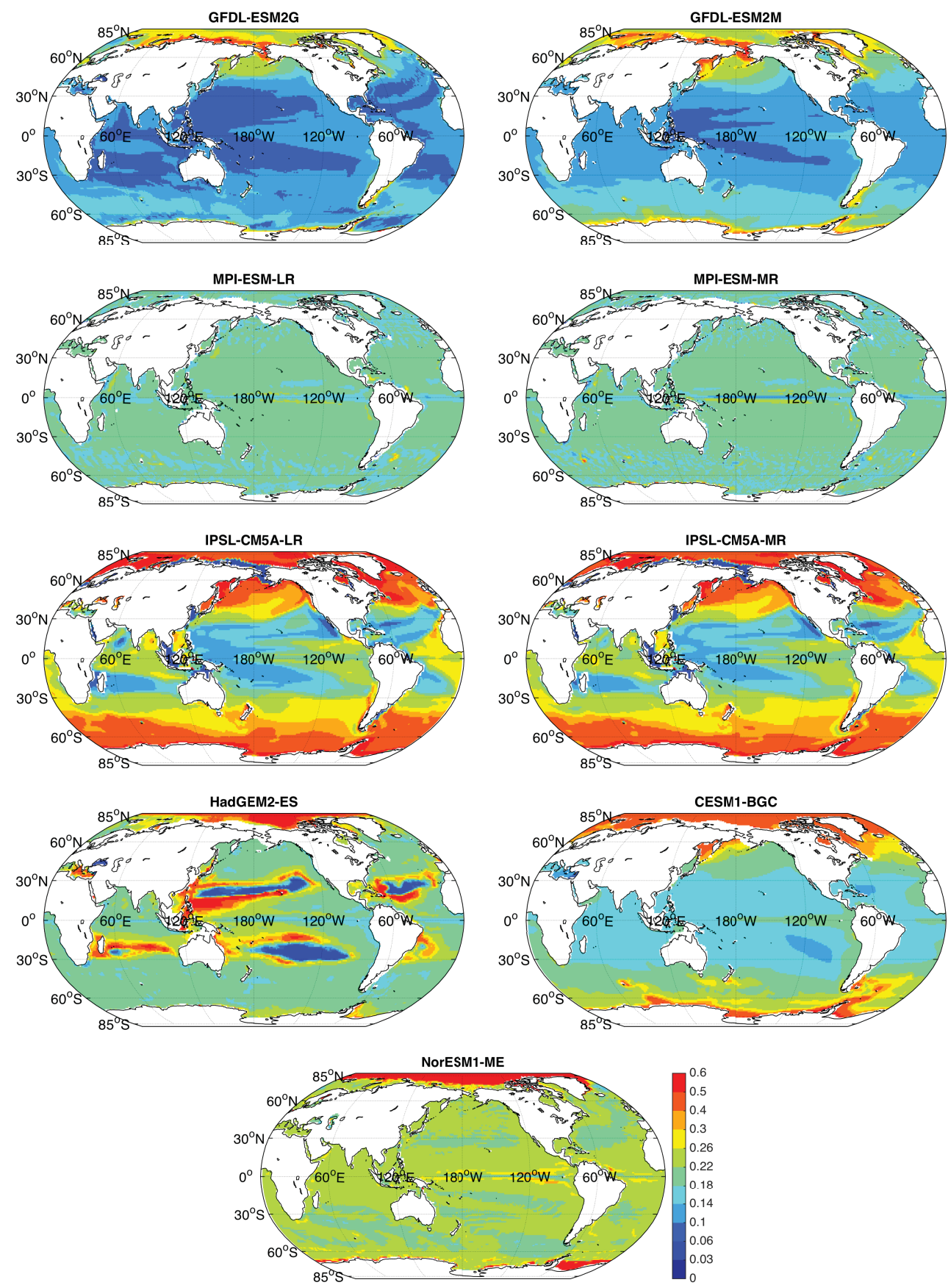

Figure 10. The mean pe-ratio for the 1990s is shown for each model.

set of models has consistent trends of increasing stratification and decreasing NPP and EP. However, a large model spread is apparent for the 1990s, particularly for NPP, and in the relative changes to NPP and EP over the 21st century due to climate change. NPP is reduced by $2-18 \%$ in the 2090 s and EP is reduced by $7-20 \%$. Mean stratification increased by $16 \%$ (GFDL-ESM2M) up to $33 \%$ (HadGEM1-ES) from the 1990s to the 2090s. Under strong warming scenarios like $\mathrm{RCP} 8.5$, ocean stratification will continue to rapidly increase after the year 2100 in all of these models (Randerson et al., 2015).

The strongly linear relationship between stratification increases and EP decreases seen within each model and across all the models (Figs. 7 and 12) indicates a strong bottomup control on EP, through declining upward nutrient flux to the euphotic zone. Declining surface nutrient concentrations are seen in all the models with climate change under the RCP8.5 scenario (Figs. 5-6). Nitrate is reduced by 3- 

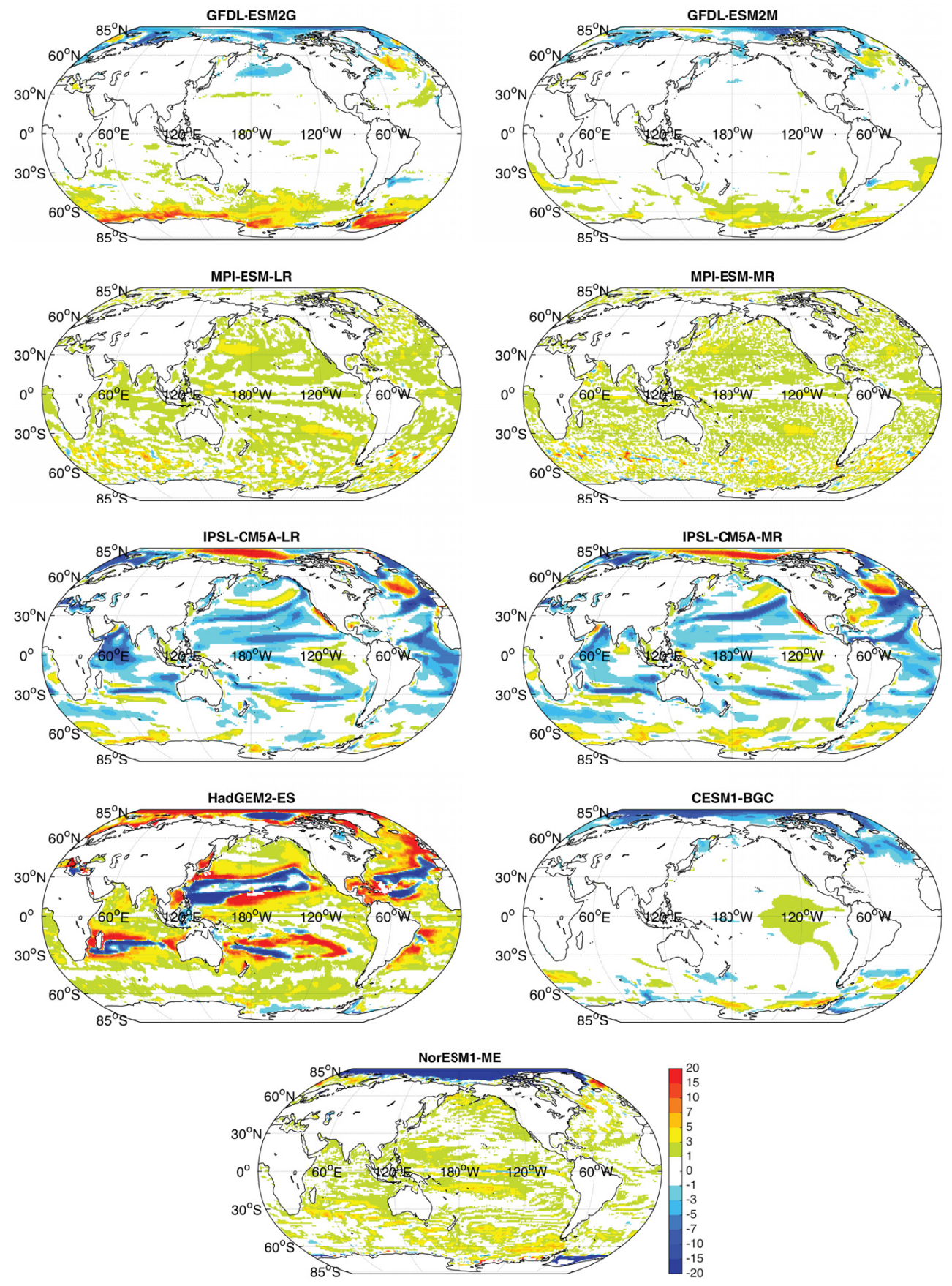

Figure 11. The percent change in the pe-ratio between the 2090s and the 1990s).

$14 \%$ and phosphate is reduced by $3-20 \%$. Changes in surface silicic acid and iron concentrations are more variable across the models. For silicic acid, there are three models showing slight increases, while the others exhibit decreases of $5-17 \%$. With respect to iron, eight models indicate an increase of $4-10 \%$ relative to the 1990 s, with the exception being the NorESM-ME model, which is reduced by $3 \%$. Changes in the temperature and light fields also have impacts on EP in some regions, but increasing stratification and nu- trient stress and the resulting impacts on phytoplankton community composition and EP is the dominant process at the global scale. On a global scale, over the full 1850-2100 time period, the changes in NPP and EP are more highly correlated with the changes in stratification than with the changes in SST $\left(r^{2}=0.72\right.$ for stratification-NPP and 0.66 for SSTNPP, Fig. 7). This is because that the stratification metric captures both the temperature-driven changes that dominate at low to midlatitudes and the salinity-driven changes at higher 

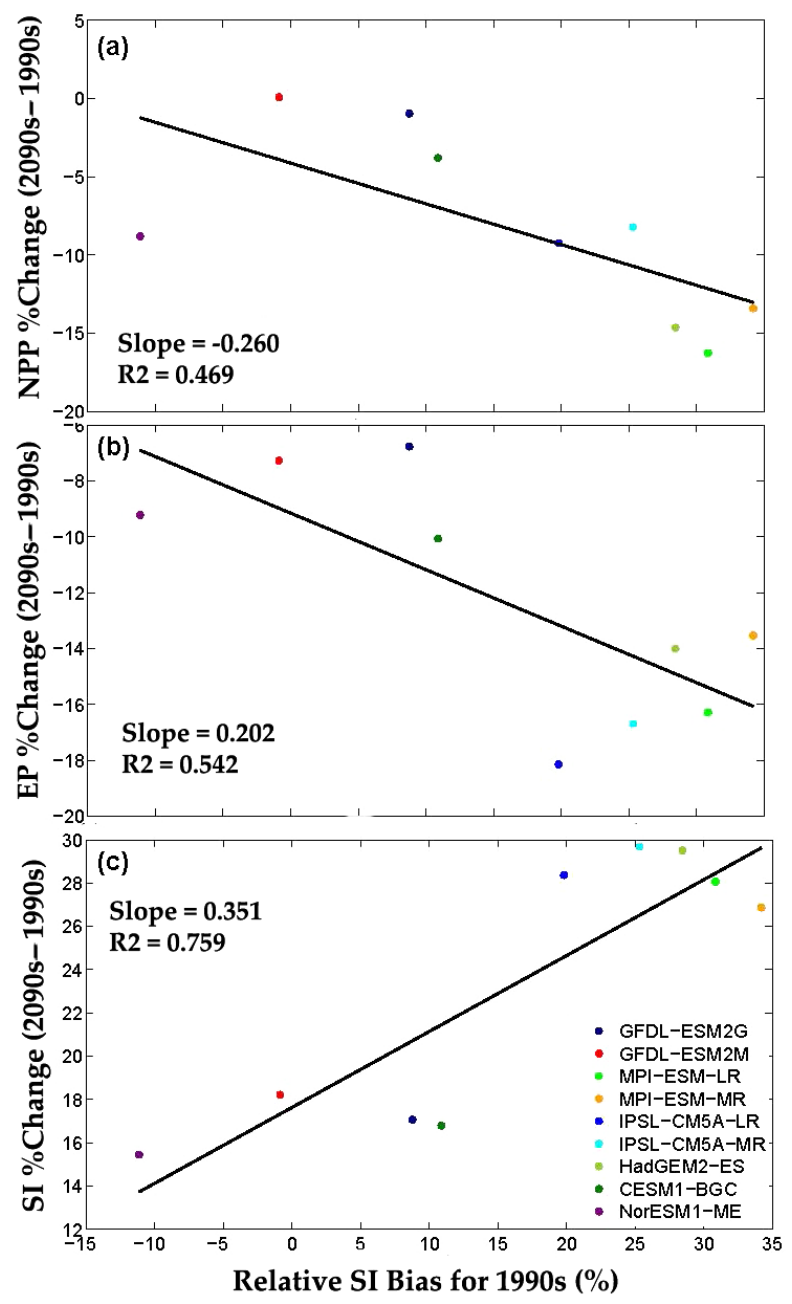

Figure 12. The stratification bias for the 1990s is plotted for each model vs. the relative changes in NPP (a), EP (b) and stratification (c) with climate change (2090s-1990s). All three linear regressions are statistically significant at a level $>95 \%$.

latitudes. The temperature-driven increases in growth rates are partially offset by reduced nutrient supply in many regions as stratification increases (Bopp et al., 2005; Cabré et al., 2015).

Simulated NPP and its response to climate change are both more variable across the models than EP, and are less strongly correlated with changes in stratification (Fig. 7). This is driven by model differences in the export efficiency of the biological pump and its relation to phytoplankton community structure. The models that allow for shifts in phytoplankton community structure show strongly nonlinear NPP response to climate change. NPP declines less rapidly than EP with increasing nutrient stress, as the percentage of NPP by large cells declines and export efficiency decreases (and the regenerated production fraction increases). Models without this dynamic community composition and export efficiency show a much more linear NPP response to climate change (Fig. 7). Thus, projections of the response of NPP to climate change in the CMIP5 models are critically dependent on the simulated phytoplankton community structure, the efficiency of the biological pump and the resulting (highly variable) levels of regenerated production.

Spatial patterns of diatom productivity are influenced by changes in surface nutrients and the resulting shifts in plankton community composition. The response of the \%NPP by diatoms depends on several factors, including whether they were a small or large component of the community initially. Therefore, the spatial patterns of changes in stratification and $\%$ NPP by diatoms can differ (Figs. 2 and 9). The largest decreases are seen in areas with high diatom production initially and large increases in stratification, particularly in the Northern Hemisphere, leading to a north-south hemispheric asymmetry (Marinov et al., 2013; Cabré et al., 2015). In the Southern Ocean, the winds that drive upwelling, strengthen and shift poleward with climate change, influencing iron supply and productivity patterns (Moore et al., 2013; Misumi et al., 2014; Leung et al., 2015).

The large spread in the simulated NPP rates for the 1990s and the variability seen across models in the response of NPP to climate change introduce challenges for climate impact and risk assessment, as NPP is a key product of both terrestrial and marine ecosystem models, and changes to NPP are perhaps the most cited result from this class of models. We have demonstrated that the wide spread seen in simulated NPP is not due to the different physical circulation models and the flux of nutrients they deliver to surface waters, but rather to the efficiency of the biological pump (tied to community structure in most models) and the resulting levels of regenerated primary production. Changes in EP are an additional useful metric of climate impacts on marine ecosystems. EP is more strongly tied to the climate feedback, as it is mainly the fixed carbon sequestered to the deeper ocean by the biological pump that will impact air-sea $\mathrm{CO}_{2}$ exchange. In addition, in terms of impacts up the food chain, EP may be a better metric than NPP. Friedland et al. (2012) demonstrated that there is no correlation between fishery yield and NPP at the global scale, but that there are strong correlations between fishery yield and several other variables including chlorophyll concentration, the pe-ratio and EP. These three proxies all correlate with the fraction of primary production by large phytoplankton. In this context, the results presented here suggest large future declines in fishery yield across the high-latitude North Atlantic.

Laufkötter et al. (2015) suggest a strong impact of temperature modification of phytoplankton growth rates and other ecosystem processes (including zooplankton growth and grazing rates) to infer a strong top-down grazing influence on the NPP response to climate change, noting that phytoplankton growth rates appear to increase at low latitudes in some models, even as available nutrient concentrations decline. However, many of the key fluxes and fields needed to support this hypothesis were not available in the archived 
output from the CMIP5 models. This study relied on estimated nutrient limitation factors and growth rates for only the surface ocean in their analysis. Temperature warming is strongest at the surface (Fig. 1S). Thus, the analysis may overestimate the temperature impacts for the whole euphotic zone. Their conclusions were based on diatom-specific nutrient limitation patterns, on the phytoplankton group with the largest changes in limitation factors and on comparing total grazing with total NPP for some models (Figs. 6-8, Laufkötter et al., 2015). These may not be representative of the community nutrient limitation patterns and growth response. At low latitudes the diatoms might show the biggest declines in growth due to nutrient limitation, but they are only a small component of the community in many of the models (Fig. 8). Under increasing nutrient stress, phytoplankton community growth rates may increase simply due to a declining contribution from diatoms, as the smaller phytoplankton will typically grow faster at low nutrient concentrations. Grazing rates are also higher on the small phytoplankton in models with multiple groups. Thus, comparing total grazing rates to NPP cannot account for these influences of phytoplankton community shifts. A community shift towards smaller phytoplankton will likely increase mean community growth rate and total grazing, even with no change in temperature.

We agree that temperature effects may be important in the NPP climate change response, and that the temperature influence on phytoplankton growth rates and on the ecosystem processing of NPP that leads to export are highly uncertain (Laufkötter et al., 2015). Sherman et al. (2016) compiled in situ estimates of phytoplankton community growth rates at the global scale and found a relatively weak apparent temperature effect (apparent $Q_{10} \sim 1.5$ ). These observational estimates of phytoplankton community growth rates were compared with the CESM and GFDL CMIP5 simulations analyzed here. ESMs used in climate change studies need to ensure that the emergent, community temperature-growth relation matches this observed value (even though higher explicit $Q_{10}$ values may be prescribed for individual plankton functional types) to avoid biases in the response to temperature change (Sherman et al., 2016).

Some of the CMIP5 models have an assumed higher export efficiency for diatoms relative to small phytoplankton, building on a long-standing paradigm, strengthened by results from the detailed ecosystem studies of the Joint Global Flux Study (JGOFS) program (Buesseler, 1998; Boyd and Newton, 1999). In the current models, the spectrum of phytoplankton size structure is often represented very simply with only the end members of one large and one small phytoplankton group. Thus, the diatom group is a proxy for larger, efficiently exporting, blooming phytoplankton functional types. DOM cycling, heterotrophic bacteria, microzooplankton and the microbial loop are typically treated in an idealized, implicit manner in the current models as well.

To accurately predict the response of NPP and EP to climate change, it may be necessary to develop more robust ecosystem models with additional explicit phytoplankton, heterotrophic microbial and zooplankton groups, including their impacts on nutrient cycling, export efficiency and the downward transport of organic matter. Models that include much greater diversity in the phytoplankton show large community composition shifts with climate change (Dutkiewicz et al., 2013). Quantifying the links between NPP, EP and community composition in observational data sets is a high priority. There are only limited field observations of the peratio, some of which rely on nutrient drawdown and other indirect estimates of the sinking particle flux (Dunne et al., 2007). Further progress to improve model performance requires combined efforts from satellite, field and laboratory observations, empirical and inverse modeling approaches, as well as process-based, forward models.

The large model spread in EP and NPP, and significant biases seen in key nutrient fields for the 1990s suggest that the current ocean biogeochemical models are far from perfect and their results must be interpreted with caution. However, the relationships between stratification and EP, NPP and nutrients do reveal some common mechanisms driving the climate change response. The large intermodel differences for the current era in NPP, EP and nutrient concentrations are partially associated with how these biogeochemical models are initialized and spun up for these experiments. The ocean biogeochemical models are often integrated in an offline mode for a thousand years or more before coupling to other components of the ESM (Séférian et al., 2016). The achieved preindustrial, near-steady state of biogeochemical fields may deviate substantially from the observed climatology, driven by biases in the physics and biogeochemistry. These differences typically persist in the present-day simulations and future projections. The advantage of the initialization and spin-up process is that the biogeochemical fields are consistent with the simulated ocean circulation, and will respond to climate-driven changes appropriately. The strong intrinsic variability helps to reduce model drift and generate reasonable longer-term variability. As a result, these long-term simulations are suitable for analyzing climate trends, variability and sensitivities. RCP8.5 is a strong warming scenario and the relationship between stratification changes and NPP/EP changes may be somewhat different under other RCP scenarios. Although the relations between the degree of surface warming and the ocean biogeochemical responses were largely linear across RCP4.5 and 8.5 for the CESM(BGC) (Moore et al., 2013), some potentially important marine biogeochemical feedbacks on the climate system were missing completely or not well represented in the CMIP5 models, including important feedbacks through aerosol transport and deposition on the marine iron cycle, feedbacks involving the oxygen minimum zones and the marine nitrogen cycle, and the impacts on ocean biology by ongoing ocean acidification. Each of these feedbacks could impact phytoplankton and zooplankton community structures, NPP, EP and pe-ratios in the future. 
It is also important to consider the longer-term climate change responses of both ocean physics and marine biogeochemistry. Moore et al. (2013) noted that climate impacts on the oceans were still accelerating in the year 2100 under the RCP8.5 scenario (but not under the more moderate RCP4.5 scenario). Randerson et al. (2015) extended the CESM1(BGC) RCP8.5 scenario simulation examined here to the year 2300. In these longer simulations, the climate impacts on ocean physical fields and biogeochemistry led to even stronger perturbations after 2100 than those presented here. In addition, the ocean contribution to the climatecarbon feedback exceeded the land contribution after the year 2100 (Randerson et al., 2015).

\section{Data availability}

CMIP5 Data used in all figures can be obtained from ftp: //ftp.ceda.ac.uk//badc/cmip5/data/cmip5/output1/.

\section{The Supplement related to this article is available online at doi:10.5194/bg-13-5151-2016-supplement.}

Acknowledgements. We are grateful for support from the US Department of Energy Office of Science and the National Science Foundation (NSF). This contribution was supported by a grant to UCI as a part of the BGC Feedbacks Scientific Focus Area within the Regional and Global Climate Modeling (RGCM) Program in the Climate and Environmental Sciences Division (CESD) of the Biological and Environmental Research (BER) Program in the US Department of Energy Office of Science. We also received funding from the NSF project "Collaborative Research: Improved Regional and Decadal Predictions of the Carbon Cycle" (AGS-1048890). We would also like to thank all those in the CMIP5 project efforts which made this work possible.

Edited by: F. Chai

Reviewed by: two anonymous referees

\section{References}

Alvain, S., Moulin, C., Dandonneau, Y., and Breon, F. M.: Remote sensing of phytoplankton groups in case 1 waters from global SeaWiFS imagery, Deep-Sea Res. Pt. I, 52, 1989-2004, 2005.

Aumont, O. and Bopp, L.: Globalizing results from ocean in situ iron fertilization studies, Global Biogeochem. Cy., 20, GB2017, doi:10.1029/2005GB002591, 2006.

Azam, F., Fenchel, T., Field, J. G., Gray, J. S., Meyerreil, L. A., and Thingstad, F.: The Ecological Role Of Water-Column Microbes In The Sea, Mar. Ecol.-Prog. Ser., 10, 257-263, 1983.

Behrenfeld, M. J., O’Malley, R. T., Siegel, D. A., McClain, C. R., Sarmiento, J. L., Feldman, G. C., Milligan, A. J., Falkowski, P. G., Letelier, R. M., and Boss, E. S.: Climate-driven trends in contemporary ocean productivity, Nature, 444, 752-755, 2006.
Bentsen, M., Bethke, I., Debernard, J. B., Iversen, T., Kirkevåg, A., Seland, Ø., Drange, H., Roelandt, C., Seierstad, I. A., Hoose, C., and Kristjánsson, J. E.: The Norwegian Earth System Model, NorESM1-M - Part 1: Description and basic evaluation of the physical climate, Geosci. Model Dev., 6, 687-720, doi:10.5194/gmd-6-687-2013, 2013.

Bindoff, N. L., Willebrand, J., Artale, V., Cazenave, A., Gregory, J. M., Gulev, S., Hanawa, K., Le Quéré, C., Levitus, S., and Nojiri, Y.: Observations: oceanic climate change and sea level, Cambridge University Press, Cambridge, 2007.

Bopp, L., Monfray, P., Aumont, O., Dufresne, J. L., Le Treut, H., Madec, G., Terray, L., and Orr, J. C.: Potential impact of climate change on marine export production, Global Biogeochem. Cy., 15, 81-99, doi:10.1029/1999gb001256, 2001.

Bopp, L., Aumont, O., Cadule, P., Alvain, S., and Gehlen, M.: Response of diatoms distribution to global warming and potential implications: A global model study, Geophys. Res. Lett., 32, L19606, doi:10.1029/2005g1023653, 2005.

Bopp, L., Resplandy, L., Orr, J. C., Doney, S. C., Dunne, J. P., Gehlen, M., Halloran, P., Heinze, C., Ilyina, T., Séférian, R., Tjiputra, J., and Vichi, M.: Multiple stressors of ocean ecosystems in the 21st century: projections with CMIP5 models, Biogeosciences, 10, 6225-6245, doi:10.5194/bg-10-6225-2013, 2013.

Boyd, P. W. and Newton, P. P.: Does planktonic community structure determine downward particulate organic carbon flux in different oceanic provinces?, Deep-Sea Res. Pt. I, 46, 63-91, 1999.

Buesseler, K. O.: The decoupling of production and particulate export in the surface ocean, Global Biogeochem. Cy., 12, 297-310, doi:10.1029/97gb03366, 1998.

Buitenhuis, E. T., Vogt, M., Moriarty, R., Bednaršek, N., Doney, S. C., Leblanc, K., Le Quéré, C., Luo, Y.-W., O’Brien, C., O’Brien, T., Peloquin, J., Schiebel, R., and Swan, C.: MAREDAT: towards a world atlas of MARine Ecosystem DATa, Earth Syst. Sci. Data, 5, 227-239, doi:10.5194/essd-5-227-2013, 2013.

Cabré, A., Marinov, I., and Leung, S.: Consistent global responses of marine ecosystems to future climate change across the IPCC AR5 earth system models, Clim. Dynam., 45, 1253-1280, doi:10.1007/s00382-014-2374-3, 2015.

Capotondi, A., Alexander, M. A., Bond, N. A., Curchitser, E. N., and Scott, J. D.: Enhanced upper ocean stratification with climate change in the CMIP3 models, J. Geophys. Res.-Oceans, 117, C04031, doi:10.1029/2011JC007409, 2012.

Carr, M.-E., Friedrichs, M. A. M., Schmeltz, M., Aita, M. N., Antoine, D., Arrigo, K. R., Asanuma, I., Aumont, O., Barber, R., Behrenfeld, M., Bidigare, R., Buitenhuis, E. T., Campbell, J., Ciotti, A., Dierssen, H., Dowell, M., Dunne, J., Esaias, W., Gentili, B., Gregg, W., Groom, S., Hoepffner, N., Ishizaka, J., Kameda, T., Le Quere, C., Lohrenz, S., Marra, J., Melin, F., Moore, K., Morel, A., Reddy, T. E., Ryan, J., Scardi, M., Smyth, T., Turpie, K., Tilstone, G., Waters, K., and Yamanaka, Y.: A comparison of global estimates of marine primary production from ocean color, Deep-Sea Res. Pt. II, 53, 741-770, 2006.

Cheng, W., Chiang, J. C. H., and Zhang, D.: Atlantic Meridional Overturning Circulation (AMOC) in CMIP5 Models: RCP and Historical Simulations, J. Climate, 26, 7187-7197, 2013.

Collins, W. J., Bellouin, N., Doutriaux-Boucher, M., Gedney, N., Halloran, P., Hinton, T., Hughes, J., Jones, C. D., Joshi, M., Liddicoat, S., Martin, G., O’Connor, F., Rae, J., Senior, C., Sitch, S., 
Totterdell, I., Wiltshire, A., and Woodward, S.: Development and evaluation of an Earth-System model-HadGEM2, Geosci. Model Dev., 4, 1051-1075, doi:10.5194/gmd-4-1051-2011, 2011.

Doney, S. C., Lima, I., Moore, J. K., Lindsay, K., Behrenfeld, M. J., Westberry, T. K., Mahowald, N., Glover, D. M., and Takahashi, T., Skill metrics for confronting global upper ocean ecosystembiogeochemistry models against field and remote sensing data, J. Mar. Systems, 76, 95-112, 2009.

Dufresne, J.-L., Foujols, M.-A., Denvil, S., Caubel, A., et al.: Climate change projections using the IPSL-CM5 Earth System Model: from CMIP3 to CMIP5, Clim Dyn., 40, 2123-2165, doi:10.1007/s00382-012-1636-1, 2013.

Dugdale, R. C. and Goering, J. J.: Uptake of new and regenerated forms of nitrogen in primary productivity, Limnol. Oceanogr., 12, 196-206, 1967.

Dunne, J. P., Sarmiento, J. L., and Gnanadesikan, A.: A synthesis of global particle export from the surface ocean and cycling through the ocean interior and on the seafloor, Global Biogeochem. Cy., 21, GB4006, doi:10.1029/2006GB002907, 2007.

Dunne, J. P., John, J., Adcroft, A., Griffies, S. M., Hallberg, R. W., Shevliakova, E., Stouffer, R. J., et al.: GFDL's ESM2 global coupled climate-carbon Earth System Models Part I: Physical formulation and baseline simulation characteristics, J. Clim., 25, doi:10.1175/JCLI-D-11-00560.1, 2013a.

Dunne, J. P., John, J. G., Shevliakova, E., Stouffer, R. J., et al.: GFDL's ESM2 global coupled climate-carbon Earth System Models Part II: Carbon system formulation and baseline simulation characteristics, J. Clim., doi:10.1175/JCLI-D-12-00150.1, 2013 b.

Dutkiewicz, S., Scott, J. R., and Follows, M. J.: Winners and losers: Ecological and biogeochemical changes in a warming ocean, Global Biogeochem. Cy., 27, 463-477, doi:10.1002/Gbc.20042, 2013.

Eppley, R. W. and Peterson, B. J.: Particulate Organic-Matter Flux And Planktonic New Production In The Deep Ocean, Nature, 282, 677-680, 1979.

Friedland, K. D., Stock, C., Drinkwater, K. F., Link, J. S., Leaf, R. T., Shank, B. V., Rose, J. M., Pilskaln, C. H., and Fogarty, M. J.: Pathways between primary production and fisheries yields of large marine ecosystems, PLoS One, 7, e28945, doi:10.1371/journal.pone.0028945, 2012.

Fung, I. Y., Doney, S. C., Lindsay, K., and John, J.: Evolution of carbon sinks in a changing climate, P. Natl. Acad. Sci. USA, 102, 11201-11206, 2005.

Gent, P. R., Danabasoglu, G., Donner, L. J., Holland, M. M., Hunke, E. C., Jayne, S. R., Lawrence, D. M., Neale, R. B., Rasch, P. J., Vertenstein, M., Worley, P. H., Yang, Z.-L., and Zhang, M.: The Community Climate System Model version 4, J. Climate, 24, 4973-4991, 2011

Giorgetta, M. A., Jungclaus, J. H., Reick, C. H., Legutke, S., Brovkin, V., Crueger, T., Esch, M., Fieg, K., Glushak, K., Gayler, V., Haak, H., Hollweg, H.-D., Ilyina, T., Kinne, S., Kornblueh, L., Matei, D., Mauritsen, T., Mikolajewicz, U., Mueller, W. A., Notz, D., Raddatz, T., Rast, S., Redler, R., Roeckner, E., Schmidt, H., Schnur, R., Segschneider, J., Six, K., Stockhause, M., Wegner, J., Widmann, H., Wieners, K.-H., Claussen, M., Marotzke, J., and Stevens, B.: Climate change from 1850 to 2100 in MPI-ESM simulations for the Coupled Model Intercomparison Project, 5, doi:10.1002/jame.20038, 2013.
Goldstein, B., Joos, F., and Stocker, T. F.: A modeling study of oceanic nitrous oxide during the Younger Dryas cold period, Geophys. Res. Lett., 30, 1092, doi:10.1029/2002gl016418, 2003.

Hannon, E., Boyd, P. W., Silvoso, M., and Lancelot, C.: Modeling the bloom evolution and carbon flows during SOIREE: Implications for future in situ iron-enrichments in the Southern Ocean, Deep-Sea Res. Pt. II, 48, 2745-2773, 2001.

Hauck, J. and Volker, C.: Rising atmospheric $\mathrm{CO}_{2}$ leads to large impact of biology on Southern Ocean $\mathrm{CO}_{2}$ uptake via changes of the Revelle factor, Geophys. Res. Lett., 42, 1459-1464, doi:10.1002/2015g1063070, 2015.

Hirata, T., Aiken, J., Hardman-Mountford, N., Smyth, T. J., and Barlow, R. G.: An absorption model to determine phytoplankton size classes from satellite ocean colour, Remote Sens. Environ., 112, 3153-3159, 2008.

Hoffman, F. M., Randerson, J. T., Arora, V. K., Bao, Q., Cadule, P., Ji, D., Jones, C. D., Kawamiya, M., Khatiwala, S., Lindsay, K., Obata, A., Shevliakova, E., Six, K. D., Tjiputra, J. F., Volodin, E. M., and $\mathrm{Wu}, \mathrm{T}$.: Causes and implications of persistent atmospheric carbon dioxide biases in Earth System Models, J. Geophys. Res.-Biogeo., 119, 141-162, doi:10.1002/2013JG002381, 2014.

Ilyina, T., Six, K. D., Segschneider, J., Maier-Reimer, E., Li, H., and Nunez-Riboni, I.: The global ocean biogeochemistry model HAMOCC: Model architecture and performance as component of the MPI-Earth System Model in different CMIP5 experimental realizations, doi:10.1002/jame.20017, 2013.

Ito, T., Bracco, A., Deutsch, C., Frenzel, H., Long, M., and Takano, Y.: Sustained growth of the Southern Ocean carbon storage in a warming climate, Geophys. Res. Lett., 42, 4516-4522, doi:10.1002/2015g1064320, 2015.

Jin, X., Gruber, N., Dunne, J. P., Sarmiento, J. L., and Armstrong, R. A.: Diagnosing the contribution of phytoplankton functional groups to the production and export of particulate organic carbon, $\mathrm{CaCO}_{3}$, and opal from global nutrient and alkalinity distributions, Global Biogeochem. Cy., 20, Gb2015, doi:10.1029/2005gb002532, 2006.

Jones, C. D., Hughes, J. K., Bellouin, N., Hardiman, S. C., Jones, G. S., Knight, J., Liddicoat, S., O'Connor, F. M., Andres, R. J., Bell, C., Boo, K. O., Bozzo, A., Butchart, N., Cadule, P., Corbin, K. D., Doutriaux-Boucher, M., Friedlingstein, P., Gornall, J., Gray, L., Halloran, P. R., Hurtt, G., Ingram, W. J., Lamarque, J. F., Law, R. M., Meinshausen, M., Osprey, S., Palin, E. J., Chini, L. P., Raddatz, T., Sanderson, M. G., Sellar, A. A., Schurer, A., Valdes, P., Wood, N., Woodward, S., Yoshioka, M., and Zerroukat, M.: The HadGEM2-ES implementation of CMIP5 centennial simulations, Geosci. Model Dev., 4, 543-570, doi:10.5194/gmd-4-5432011, 2011.

Knutti, R. and Hegerl, G. C.: The equilibrium sensitivity of the Earth's temperature to radiation changes, Nat. Geosci., 1, 735743, doi:10.1038/ngeo1337, 2008.

Kostadinov, T. S., Siegel, D. A., and Maritorena, S.: Retrieval of the particle size distribution from satellite ocean color observations, J. Geophys. Res.-Oceans, 114, C09015, doi:10.1029/2009JC005303, 2009.

Kuhlbrodt, T. and Gregory, J. M.: Ocean heat uptake and its consequences for the magnitude of sea level rise and climate change, Geophys. Res. Lett., 39, L18608, doi:10.1029/2012GL052952, 2012. 
Laufkötter, C., Vogt, M., Gruber, N., Aita-Noguchi, M., Aumont, O., Bopp, L., Buitenhuis, E., Doney, S. C., Dunne, J., Hashioka, T., Hauck, J., Hirata, T., John, J., Le Quéré, C., Lima, I. D., Nakano, H., Seferian, R., Totterdell, I., Vichi, M., and Völker, C.: Drivers and uncertainties of future global marine primary production in marine ecosystem models, Biogeosciences, 12, 69556984, doi:10.5194/bg-12-6955-2015, 2015.

Le Quéré, C., Harrison, S. P., Prentice, I. C., Buitenhuis, E. T., Aumont, O., Bopp, L., Claustre, H., Da Cunha, L. C., Geider, R., Giraud, X., Klaas, C., Kohfeld, K. E., Legendre, L., Manizza, M., Platt, T., Rivkin, R. B., Sathyendranath, S., Uitz, J., Watson, A. J., and Wolf-Gladrow, D.: Ecosystem dynamics based on plankton functional types for global ocean biogeochemistry models, Glob. Change Biol., 11, 2016-2040, 2005.

Leung, S., Cabré, A., and Marinov, I.: A latitudinally banded phytoplankton response to 21 st century climate change in the Southern Ocean across the CMIP5 model suite, Biogeosciences, 12, 57155734, doi:10.5194/bg-12-5715-2015, 2015.

Lindsay, K., G. B. Bonan, Doney, S. C, Hoffmann, F. M., Lawrence, D. M., Long, M. C., Mahowald, N. M., Moore, J. K., Randerson, J. T., and Thornton, P. E.: Preindustrial control and 20th century carbon cycle experiments with the earth system model CESM1 (BGC), J. Climate, 27, 8981-9005, 2014.

Liu, M., Rajagopalan, K., Chung, S. H., Jiang, X., Harrison, J., Nergui, T., Guenther, A., Miller, C., Reyes, J., Tague, C., Choate, J., Salathé, E. P., Stöckle, C. O., and Adam, J. C.: What is the importance of climate model bias when projecting the impacts of climate change on land surface processes?, Biogeosciences, 11, 2601-2622, doi:10.5194/bg-11-2601-2014, 2014.

Luo, Y. Y., Liu, Q. Y., and Rothstein, L. M.: Simulated response of North Pacific Mode Waters to global warming, Geophys. Res. Lett., 36, L23609, doi:10.1029/2009GL040906, 2009.

Lyman, J. M., Good, S. A., Gouretski, V. V., Ishii, M., Johnson, G. C., Palmer, M. D., Smith, D. M., and Willis, J. K.: Robust warming of the global upper ocean, Nature, 465, 334-337, 2010.

Manizza, M., Le Quere, C., Watson, A. J., and Buitenhuis, E. T.: Ocean biogeochemical response to phytoplankton-light feedback in a global model, J. Geophys. Res.-Oceans, 113, C10010, doi:10.1029/2007jc004478, 2008.

Marinov, I., Doney, S. C., Lima, I. D., Lindsay, K., Moore, J. K., and Mahowald, N.: North-South asymmetry in the modeled phytoplankton community response to climate change over the 21st century, Global Biogeochem. Cy., 27, 1274-1290, doi:10.1002/2013gb004599, 2013.

Misumi, K., Lindsay, K., Moore, J. K., Doney, S. C., Bryan, F. O., Tsumune, D., and Yoshida, Y.: The iron budget in ocean surface waters in the 20th and 21st centuries: projections by the Community Earth System Model version 1, Biogeosciences, 11, 33-55, doi:10.5194/bg-11-33-2014, 2014

Moore, J. K., Doney, S. C., and Lindsay, K.: Upper ocean ecosystem dynamics and iron cycling in a global 3-D model, Global Biogeochem. Cy., 18, GB4028, doi:10.1029/2004GB002220, 2004.

Moore, J., Lindsay, K., Doney, S., Long, M., and Misumi, K.: Marine Ecosystem Dynamics and Biogeochemical Cycling in the Community Earth System Model [CESM1(BGC)]: Comparison of the 1990s with the 2090s under the RCP4.5 and RCP8.5 Scenarios, J. Climate, 26, 9291-9312, 2013.

Moss, R. H., Edmonds, J. A., Hibbard, K. A., Manning, M. R., Rose, S. K., van Vuuren, D. P., Carter, T. R., Emori, S., Kainuma, M.,
Kram, T., Meehl, G. A., Mitchell, J. F. B., Nakicenovic, N., Riahi, K., Smith, S. J., Stouffer, R. J., Thomson, A. M., Weyant, J. P., and Wilbanks, T. J.: The next generation of scenarios for climate change research and assessment, Nature, 463, 747-756, 2010.

Palmer, J. R. and Totterdell, I. J.: Production and export in a global ocean ecosystem model, Deep-Sea Res. Pt. I, 48, 1169-1198, 2001.

Passow, U. and Carlson, C. A.: The biological pump in a high $\mathrm{CO}_{2}$ world, Mar. Ecol.-Prog. Ser., 470, 249-271, 2012.

Plattner, G. K., Joos, F., Stocker, T. F., and Marchal, O.: Feedback mechanisms and sensitivities of ocean carbon uptake under global warming, Tellus B, 53, 564-592, 2001.

Pollard, R. T., Salter, I., Sanders, R. J., Lucas, M. I., Moore, C. M., Mills, R. A., Statham, P. J., Allen, J. T., Baker, A. R., Bakker, D. C., Charette, M. A., Fielding, S., Fones, G. R., French, M., Hickman, A. E., Holland, R. J., Hughes, J. A., Jickells, T. D., Lampitt, R. S., Morris, P. J., Nedelec, F. H., Nielsdottir, M., Planquette, H., Popova, E. E., Poulton, A. J., Read, J. F., Seeyave, S., Smith, T., Stinchcombe, M., Taylor, S., Thomalla, S., Venables, H. J., Williamson, R., and Zubkov, M. V.: Southern Ocean deep-water carbon export enhanced by natural iron fertilization, Nature, 457 , 577-581, 2009.

Pomeroy, L. R.: The ocean's food web, a changing paradigm, Bioscience, 24, 499-504, 1974.

Randerson, J. T., Lindsay, K., Munoz, E., Fu, W., Moore, J. K., Hoffman, F. M., Mahowald, N. M., and Doney, S. C.: Multicentury changes in ocean and land contributions to the climate-carbon feedback, Global Biogeochem. Cy., 29, 744-759, doi:10.1002/2014gb005079, 2015.

Schmittner, A., Oschlies, A., Matthews, H. D., and Galbraith, E. D.: Future changes in climate, ocean circulation, ecosystems, and biogeochemical cycling simulated for a business-as-usual $\mathrm{CO}_{2}$ emission scenario until year $4000 \mathrm{AD}$, Global Biogeochem. Cy., 22, Gb1013, doi:10.1029/2007gb002953, 2008.

Schwinger, J., Tjiputra, J. F., Heinze, C., Bopp, L., Christian, J. R., Gehlen, M., Ilyina, T., Jones, C. D., Salas-Melia, D., Segschneider, J., Séférian, R., and Totterdell, I.: Nonlinearity of Ocean Carbon Cycle Feedbacks in CMIP5 Earth System Models, J. Climate, 27, 3869-3888, 2014.

Seferian, R., Bopp, L., Gehlen, M., Orr, J. C., Ethe, C., Cadule, P., Aumont, O., Salas y Melia, D., Voldoire, A., and Madec, G.: Skill assessment of three earth system models with common marine biogeochemistry, Clim. Dynam., 40, 2549-2573, doi:10.1007/s00382-012-1362-8, 2013.

Séférian, R., Gehlen, M., Bopp, L., Resplandy, L., Orr, J. C., Marti, O., Dunne, J. P., Christian, J. R., Doney, S. C., Ilyina, T., Lindsay, K., Halloran, P. R., Heinze, C., Segschneider, J., Tjiputra, J., Aumont, O., and Romanou, A.: Inconsistent strategies to spin up models in CMIP5: implications for ocean biogeochemical model performance assessment, Geosci. Model Dev., 9, 1827 1851, doi:10.5194/gmd-9-1827-2016, 2016.

Sherman, E., Moore, J. K., Primeau, F., and Tanouye, D.: Temperature influence on phytoplankton community growth rates, Global Biogeochem. Cy., 30, 550-559, doi:10.1002/2015GB005272, 2016.

Siegel, D. A., Buesseler, K. O., Doney, S. C., Sailley, S. F., Behrenfeld, M. J., and Boyd, P. W.: Global assessment of ocean carbon export by combining satellite observations and 
food-web models, Global Biogeochem. Cy., 28, 181-196, doi:10.1002/2013gb004743, 2014.

Siegenthaler, U. and Wenk, T.: Rapid Atmospheric $\mathrm{CO}_{2}$ Variations And Ocean Circulation, Nature, 308, 624-626, 1984.

Steinacher, M., Joos, F., Frölicher, T. L., Plattner, G.-K., and Doney, S. C.: Imminent ocean acidification in the Arctic projected with the NCAR global coupled carbon cycle-climate model, Biogeosciences, 6, 515-533, doi:10.5194/bg-6-515-2009, 2009.

Steinacher, M., Joos, F., Frölicher, T. L., Bopp, L., Cadule, P., Cocco, V., Doney, S. C., Gehlen, M., Lindsay, K., Moore, J. K., Schneider, B., and Segschneider, J.: Projected 21st century decrease in marine productivity: a multi-model analysis, Biogeosciences, 7, 979-1005, doi:10.5194/bg-7-979-2010, 2010.

Swart, N. C. and Fyfe, J. C.: Observed and simulated changes in the Southern Hemisphere surface westerly wind-stress, Geophys. Res. Lett., 39, L16711, doi:10.1029/2012GL052810, 2012.

Szopa, S., Balkanski, Y., Schulz, M., Bekki, S., Cugnet, D., Fortems-Cheiney, A., Turquety, S., Cozic, A., Deandreis, C., Hauglustaine, D., Idelkadi, A., Lathiere, J., Lefevre, F., Marchand, M., Vuolo, R., Yan, N., and Dufresne, J. L.: Aerosol and ozone changes as forcing for climate evolution between 1850 and 2100, Clim. Dynam., 40, 2223-2250, doi:10.1007/S00382-0121408-Y, 2013.
Taylor, K. E., Stouffer, R. J., and Meehl, G. A.: An Overview Of Cmip5 And The Experiment Design, B. Am. Meteorol. Soc., 93, 485-498, 2012.

Tjiputra, J. F., Roelandt, C., Bentsen, M., Lawrence, D. M., Lorentzen, T., Schwinger, J., Seland, Ø., and Heinze, C.: Evaluation of the carbon cycle components in the Norwegian Earth System Model (NorESM), Geosci. Model Dev., 6, 301-325, doi:10.5194/gmd-6-301-2013, 2013.

Vancoppenolle, M., Bopp, L., Madec, G., Dunne, J., Ilyina, T., Halloran, P. R., and Steiner, N.: Future Arctic Ocean primary productivity from CMIP5 simulations: Uncertain outcome, but consistent mechanisms, Global Biogeochem. Cy., 27, 605-619, doi:10.1002/gbc.20055, 2013.

van Vuuren, D. P., Edmonds, J., Kainuma, M., Riahi, K., Thomson, A., Hibbard, K., Hurtt, G. C., Kram, T., Krey, V., Lamarque, J.F., Masui, T., Meinshausen, M., Nakicenovic, N., Smith, S. J., and Rose, S. K.: The representative concentration pathways: an overview, Climatic Change, 109, 5-31, 2011.

Vichi, M., Manzini, E., Fogli, P. G., Alessandri, A., Patara, L., Scoccimarro, E., Masina, S., and Navarra, A.: Global and regional ocean carbon uptake and climate change: sensitivity to a substantial mitigation scenario, Clim. Dynam., 37, 1929-1947, doi:10.1007/s00382-011-1079-0, 2011. 